\title{
Petrophysical and geochemical signature of the Hangenberg Events: an integrated stratigraphy of the Devonian-Carboniferous boundary interval in the Northern Rhenish Massif (Avalonia, Germany)
}

\author{
TOMÁŠ KUMPAN, ONDŘEJ BÁBEK, JIŘí KALVODA, TOMÁŠ MATYS GRYGAR, JIŘí FRÝDA, \\ RALPH THOMAS BECKER \& SVEN HARTENFELS
}

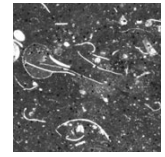

\begin{abstract}
Petrophysical (gamma-ray spectrometry, magnetic susceptibility) and geochemical (X-ray fluorescence spectrometry and inorganic carbon isotope geochemistry) methods are used for stratigraphic correlations and palaeoenvironmental interpretations of the Devonian-Carboniferous boundary interval in the northern part of the Rheinisches Schiefergebirge, Germany. Sections at Oese, Oberrödinghausen and Drewer were studied in the stratigraphic range from the Famennian Upper expansa Zone to the Tournaisian Lower crenulata Zone. The Famennian Wocklum Limestone reveals distinctive cyclicity in the limestone and shale arrangement, whose primary origin has been supported by correlation with $\mathrm{K} / \mathrm{Al}$ ratio changes. Lower-order $\mathrm{K} / \mathrm{Al}$ cyclicity follows bundles of alternating layers. On the other hand, $\mathrm{Zr} / \mathrm{Al}$ cyclicity is rather independent on facies and $\mathrm{K} / \mathrm{Al}$ and duration of $\mathrm{Zr} / \mathrm{Al}$ cycles was estimated to be $370 \mathrm{ka}$, which is close to $405 \mathrm{ka}$ eccentricity. Correlations of the curve patterns of Computed Gamma Ray, $\mathrm{U} / \mathrm{Th}_{\mathrm{GRS}}$, bulk magnetic susceptibility, K/Al, Zr/Al, S, and Mn proxies have been employed for regional correlation. Our dataset confirms previous palaeoenvironmental interpretations of the Hangenberg Events and additionally provides information on gradual decrease in a bottom oxygenation just prior the events. Peaks in redox and palaeoproductivity proxies (U/Th, $\mathrm{Cu}+\mathrm{Ni}+\mathrm{Zn}+\mathrm{Pb}$ ) occur in the Hangenberg Black Shale in all studied sections. Although sedimentation of the Hangenberg Black Shale took place during the deepening step, the enhanced palaeoproductivity and hypoxia to anoxia were the main cause of its deposition. An interregional correlation of the Devonian-Carboniferous intervals from the northern Rhenish Massif, Moravian Karst and Carnic Alps was carried out and underlines the potential for further chronostratigraphic definitions. - Key words: Famennian, Tournaisian, Hangenberg Events, gamma-ray spectrometry, magnetic susceptibility, element geochemistry, stable carbon isotope geochemistry.
\end{abstract}

Kumpan, T., BÁbek, O., Kalvoda, J., Matys Grygar, T., Frýda, J., Becker, R.T. \& Hartenfels, S. 2015. Petrophysical and geochemical signature of the Hangenberg Events: an integrated stratigraphy of the Devonian-Carboniferous boundary interval in the Northern Rhenish Massif (Avalonia, Germany). Bulletin of Geosciences 90(3), 667-694 (17 figures, 1 table). Czech Geological Survey, Prague. ISBN 1214-1119. Manuscript received December 2, 2014; accepted in revised form June 18, 2015; published online September 15, 2015; issued September 30, 2015.

Tomáš Kumpan (corresponding author), Ondřej Bábek \& Jiři Kalvoda, Department of Geological Sciences, Masaryk University, Kotlářská 2, 61137 Brno, Czech Republic; kumpan.tom@gmail.com•Ondřej Bábek, Department of Geology, Palacký University, 17. listopadu 12, 77200 Olomouc, Czech Republic • Tomáš Matys Grygar, Institute of Inorganic Chemistry, Academy of Sciences of the Czech Republic, 25068 Řež, Czech Republic • Jiří Frýda, Czech Geological Survey, Klárov 3/131, 11821 Prague 1, Czech Republic, and Department of Environmental Geosciences, Czech University of Life Sciences, Kamýcká 129, 16521 Prague 6, Czech Republic • Ralph Thomas Becker \& Sven Hartenfels, Institute of Geology and Palaeontology, Westfälische Wilhelms-Universität, Corrensstraße 24, D-48149 Münster, Germany

The late Devonian-early Carboniferous is one of the most important time intervals of Earth's history as it represents a transition from the warm mid-Palaeozoic global climate regime to the icehouse of the late Palaeozoic (Streel 1986; Kalvoda 1986, 2002; Brezinski et al. 2008). Global climatic changes were usually associated with perturbations of palaeogeographic and palaeoceanographic settings and ac- companied by ecosystem crisis (e.g., Caplan \& Bustin 1999, House 2002). Many such levels connected with mass extinction were described from late Devonian to early Carboniferous times (Walliser 1984, House 1985, Becker 1993a), such as the Kellwasser Events (latest Frasnian; e.g., Schindler 1993, Racki 2005, Gereke \& Schindler 2012, Chen et al. 2013), the Annulata Events (mid-late 


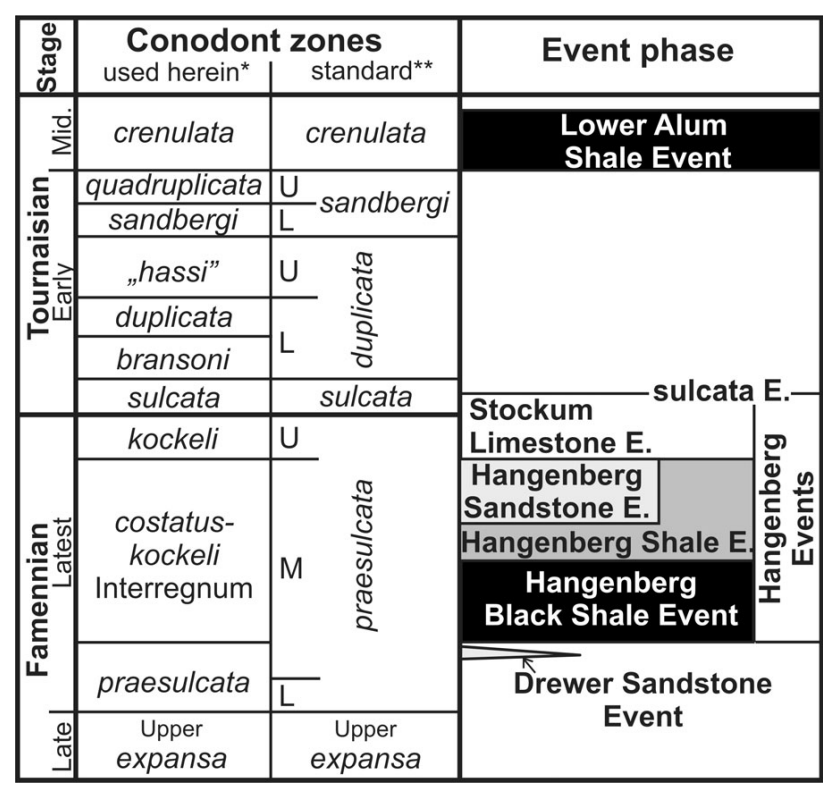

Figure 1. Conodont biostratigraphy and event stratigraphy of the late/latest Famennian and lower Tournaisian boundary interval in the type area of the Hangenberg Event in the northern Rhenish Massif (modified after Bless et al. 1993, Kaiser et al. 2011). Conodont zonations sensu Sandberg et al. (1978)* and Kaiser et al. (2009)**.

Famennian; e.g., Becker 1992, Becker et al. 2004, Racka et al. 2010, Hartenfels 2011), the Dasberg Events/Crisis (late Famennian; e.g., Hartenfels \& Becker 2009, Marynowski et al. 2010, Hartenfels 2011), the Hangenberg Events/Crisis (latest Famennian to earliest Tournaisian; e.g., Walliser 1984; Marynowski \& Filipiak 1997; Kaiser et al. 2006, 2009, 2011; Marynowski et al. 2012) and mid-Tournaisian Lower Alum Shale Event (e.g., Becker 1993b, Zhuravlev 1998, Siegmund et al. 2002, Kaiser et al. 2011). Although the possible triggers of many Late Devonian events are numerous and hotly debated, an intimate link between the Gondwana glaciation (e.g., Veevers \& Powell 1987; Isaacson et al. 1999, 2008; Streel et al. 2000a; Almond et al. 2002; Caputo et al. 2008; Fielding et al. 2008) and the multiphase Hangenberg Events is generally accepted in the literature (Caplan \& Bustin 1999; Streel et al. 2000b, 2013; Streel 2002; Streel \& Marshall 2007; Isaacson et al. 2008; Kaiser et al. 2011; Wicander et al. 2011; Myrow et al. 2013).

The Hangenberg Events (HE) can be subdivided into three phases (Fig. 1). The first "pre-event" phase is the regressive Drewer Sandstone Event (Bless et al. 1993; Becker 1996: holostratigraphic level 8; Kaiser et al. 2011) recognized by fine siliciclastic deposition, increasing condensation, shallowing upwards, or by stratigraphic gaps just before the second phase - the Hangenberg Black Shale Event (HBSE; Hangenberg Event s.s.), which is manifested by globally widespread black shale deposition, carbon isotopic anomaly and mass extinction (e.g., Walliser
1984; Becker 1993a, 1993b, 1996: holostratigraphic level 9; Caplan \& Bustin 1999; Kaiser et al. 2006, 2008, 2011; Qie et al. 2015). This event was interpreted as a consequence of the upwelling of nutrient-rich waters, which led to eutrophication on shelves. Consequent high marine bioproductivity caused the demise of carbonate factories, water anoxia, and intensive burial of organic matter (Caplan \& Bustin 1996, 1998, 1999; Kaiser et al. 2006, 2008). The organic bloom critically increased the withdrawal of carbon from the atmospheric reservoir of the global carbon cycle to the organic-rich sediments. These sediments were deposited on the continents shelves and in numerous rapidly subsiding, deep foreland basins, which probably led to significant decrease in atmospheric $\mathrm{CO}_{2}$ (Algeo et al. 2001, Kaiser et al. 2006). The reduced levels of atmospheric $\mathrm{CO}_{2}$ in combination with the Gondwana passage through the southern polar region (Caplan \& Bustin 1999; Isaacson et al. 2008) caused global cooling and the growth of glaciers (Caputo et al. 2008). The rapid global cooling led to the third phase of the HE (the Hangenberg Shale and Sandstone Event; HSE), which is represented by deposition of increasingly medium to coarse-grained siliciclastic sediments in the marine environment and/or gaps in sedimentary records all over the world (Van Steenwinkel 1993, Hance et al. 1994, Becker 1996: holostratigraphic levels 10-11; Kaiser et al. 2011, Myrow et al. 2013, Kumpan et al. 2014b).

The global extent and abrupt nature of these events led Walliser (1984) to propose the base of the HBSE as a natural Devonian-Carboniferous boundary (DCB). However, his proposal was abandoned during the subsequent definition of the DCB. The current standard DCB definition, which is based on the first appearance of the conodont Siphonodella sulcata (Paproth et al. 1991), is problematic and requires redefinition (Kaiser 2009, Kaiser \& Corradini 2011). A possible use of other stratigraphically important fossils (advanced species of the conodont genus Protognathodus or of the foraminifer genera Quasiendothyra and Tournayellina) is even more limited (e.g., Corradini et al. 2011, Kalvoda et al. 2015). Consequently, the global palaeoenvironmental changes related to the HE may give an opportunity for auxiliary event-based solution of the DCB problem.

Petrophysical and geochemical methods, such as magnetostratigraphy or isotope chemostratigraphy, in combination with the more traditional biostratigraphy and sedimentology, may represent good stratigraphic tools and provide objective ties for correlations. This approach is motivated by a successful application of isotope chemostratigraphy and magnetostratigraphy in combination with biostratigraphy for the definition of the Danian base (Keller 2011), the base of the Aquitanian (Steininger et al. 1997), and the base of the Eocene (Aubry et al. 2007). An integrated approach may therefore be helpful for the solution of the DCB definition problem. 


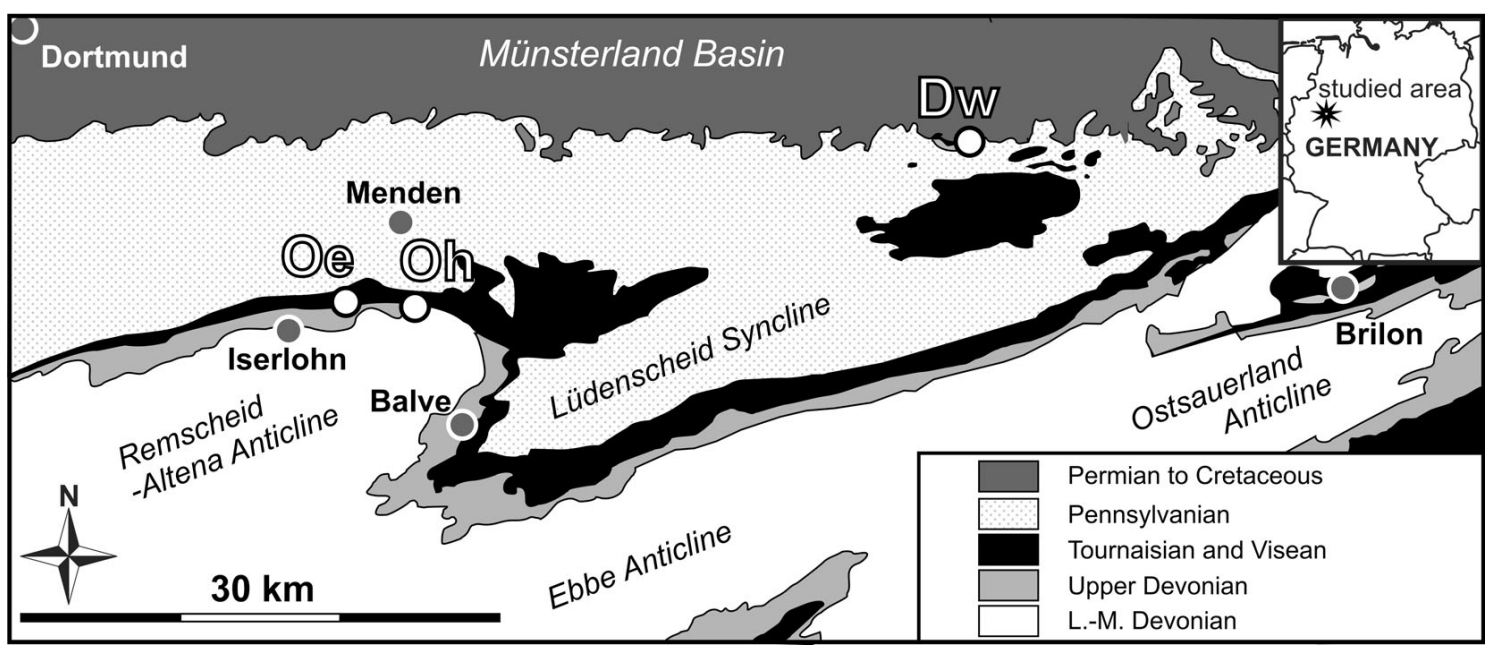

Figure 2. Simplified geological map of the northern Rheinisches Schiefergebirge with the position of the studied sections (Oe - Oese, Oh - Oberrödinghausen, Dw - Drewer). Modified after Luppold et al. (1994).

The aim of our research is to trace petrophysical and geochemical vertical changes across the DCB in the classical area of Famennian and Tournaisian stratigraphy and type area of the Hangenberg Events in the northern part of the Rhenish Massif (Korn et al. 1994, Luppold et al. 1994, Becker 1996) and to use them for stratigraphic correlations. Because of their good accessibility and stratigraphic completeness, the sections at Oese, Oberrödinghausen (railway cut) and Drewer were chosen for high-resolution petrophysical (gamma-ray spectrometry, magnetic susceptibility) and geochemical analysis (X-ray fluorescence spectrometry and inorganic carbon isotope geochemistry). The resulting multi-proxy dataset served for correlations, evaluation of the cyclostratigraphic potential of the studied sections, and interpretations of palaeoenvironmental and sea level changes.

\section{Geological setting}

The studied localities, Oese $\left(51^{\circ} 24.09057^{\prime} \mathrm{N} ; 7^{\circ}\right.$ 47.26218 ' E), Oberrödinghausen (51 ${ }^{\circ} 23^{\prime} 45.523^{\prime \prime} \mathrm{N} ; 7^{\circ} 50^{\prime}$ $23.815^{\prime \prime} \mathrm{E}$ ) and Drewer (51 $\left.{ }^{\circ} 29^{\prime} 36.592^{\prime \prime} \mathrm{N} ; 8^{\circ} 21^{\prime} 21.865^{\prime \prime} \mathrm{E}\right)$, are located in the northern part of the Rheinisches Schiefergebirge (Fig. 2), where sediments of the Rhenohercynian Basin are exposed. The Rhenohercynian Basin, a subunit of the Avalonia Plate, was dominated by block faulting and variable subsidence during the Middle to Late Devonian. Active subduction zones of the remnant and closing Rheic Ocean separated it from the Mid-German Crystalline High further to the south (Ziegler 1990, Franke 1995, Oncken \& Weber 1995, Oncken et al. 2000, Eckelmann et al. 2014).

The northern part of the Rhenish Massif represents one of the key areas for biostratigraphy at the DCB boundary with the auxiliary stratotype section at Hasselbachtal (Becker et al. 1984; Becker 1988, 1996; Becker \& Paproth
1993; Kürschner et al. 1993; Luppold et al. 1994; Korn \& Weyer 2003; Korn et al. 2010). The framework of the lithostratigraphy and ammonoid stratigraphy across the D-C boundary in the northern Rhenish Massif has been established in the pioneering papers of Schmidt (1924), Schindewolf (1937), and Vöhringer (1960). The global nature of the Hangenberg Black Shale Event was recognised by Walliser (1984). Further progress in ammonoid biostratigraphy and extinctions came in papers by Price \& House (1984), Korn (1984, 1988, 1991, 1993), Luppold et al. (1984, 1994), House (1993), Korn et al. (1994), Korn (1994, 2001), and Becker (1996). Pioneering conodont studies by Voges (1960), Ziegler (1969, 1971), Ziegler \& Leuteritz (1970), and Eickhoff (1973) served as a basis for global Palmatolepis- and Siphonodella-based zonations (Sandberg et al. 1978, Ziegler \& Sandberg 1984). More recently they were followed by Luppold et al. (1984, 1994), Clausen et al. (1989), Kürschner et al. (1993), and the bed-by-bed studies of Kaiser (2005) and Kaiser et al. (2006). Kaiser et al. (2009) revised the zonation scheme, partly based on detailed data from other European successions. Data for the bransoni Zone are not available for all sections, therefore the bransoni and duplicata zones are jointed to the duplicata (= Lower duplicata) Zone. Becker et al. (2013) noted that the defining index species of the Siphonodella hassi Zone is an invalid and yet unreplaced junior homonym - therefore, we put this zone name in inverted commas ("hassi Zone").

Oese and Oberrödinghausen localities lie on the northern flank of the Remscheid-Altena Anticline (Fig. 1), which core formed a morphological high or even island (Paproth 1986). Drewer, on the other hand, was located on the Belecke Anticline, an intrabasinal swell with starved condensed basin facies until the Viséan (Fig. 1; e.g., Clausen et al. 1989, Korn \& Weyer 2003, Korn 2010). We sampled 


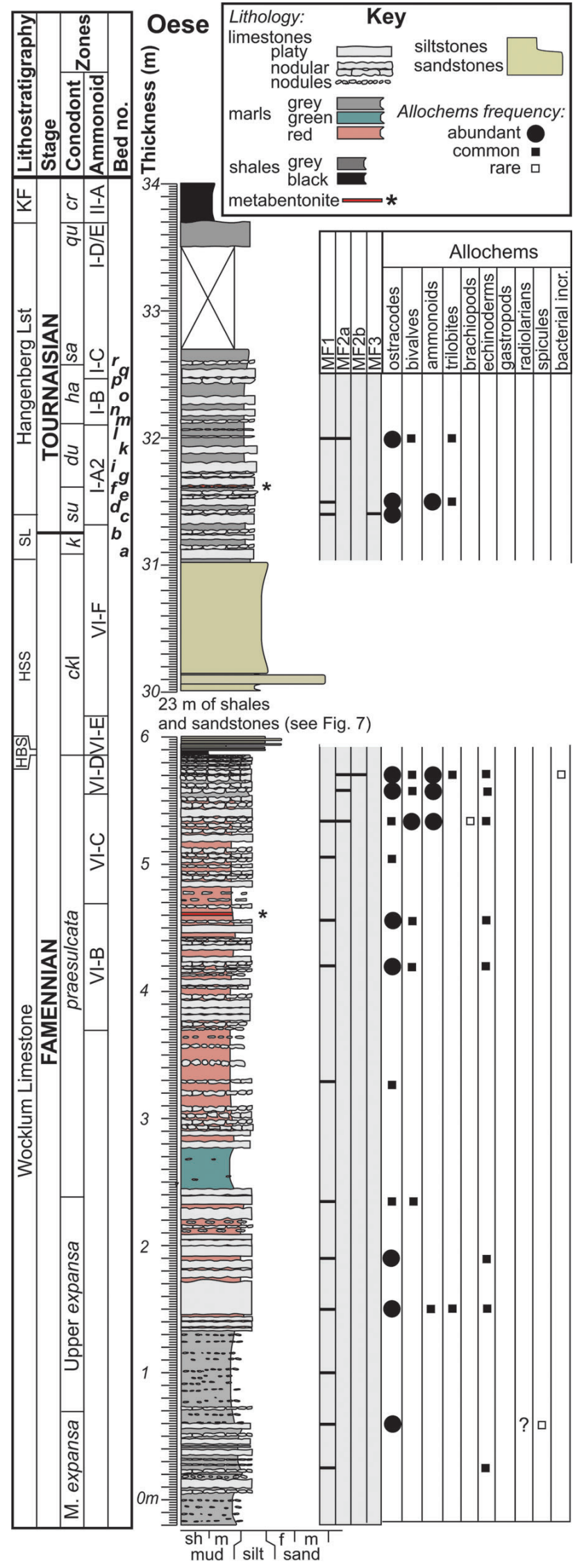

a main section (Drewer A = Section WA in Korn et al. 1994) and the laterally pinching out Drewer Sandstone just to the SW (Drewer B = Section WB of Korn et al. 1994).

The late/latest Famennian in the studied sections consists of alternating shales and nodular limestones (Wocklum Limestone), studied in stratigraphic range from the Middle expansa Zone (= aculeatus Zone) at Oese (Fig. 3) and the Upper expansa Zone in both the Oberrödinghausen (Fig. 4) and Drewer (Fig. 5) sections to the top of the praesulcata Zone (sensu Kaiser et al. 2009). The Drewer Sandstone is intercalated in the Wocklum Limestone in its upper part only at Drewer. Towards the top of the Wocklum Limestone an increase in carbonate material, the fossil content and microfacies changes have been recognised (Becker 1996, Korn \& Weyer 2003) and the lowstand or eventually highstand system tract has been interpreted for this unit (Van Steenwinkel 1993). This supposed shallowing episode is followed by the Hangenberg Black Shale (costatus-kockeli Interregnum; transgressive system tract; Van Steenwinkel 1993) and overlying siliciclastic successions of the upper part of the costatus-kockeli Interregnum. This siliciclastic succession is represented at Oese by green Hangenberg Shale terminated by the locally massive Hangenberg Sandstone (Keupp \& Kompa 1984), whereas in the more distal Oberrödinghausen section only Hangenberg Shale occurs (e.g., Paproth \& Streel 1970, Eickhoff 1973, Higgs \& Streel 1984). The Hangenberg Shale has been interpreted as a highstand system tract deposits and the Hangenberg Sandstone as slope fan of the lowstand system tract (Van Steenwinkel 1993, Kaiser et al. 2011). The siliciclastic succession is capped by the Stockum Limestone, a marly nodular limestone horizon of the kockeli Zone to basal sulcata Zone age, which is missing at Oberrödinghausen. The overlying early Tournaisian Hangenberg Limestone (sulcata to quadruplicata Zone) is mainly composed of grey nodular limestones with thin shaly interbeddings, which has been interpreted as the lowstand system tract deposits (Van Steenwinkel 1993, Siegmund et al. 2002). Its microfacies and diagenesis was studied by Van Steenwinkel (1984) and Siegmund et al. (2002). The uppermost studied unit is represented by the Kahlenberg Formation (crenulata to cuneiformis zones). It consists of highly pyritic black shales, which are successively replaced by phosphoritic black

Figure 3. A stratigraphic, lithostratigraphic and sedimentological log of the Oese section. Conodont biostratigraphy adopted from Kürschner et al. (1993), Kaiser (2005), and Nowak (2008). Ammonoid biostratigraphy based on Becker et al. (1993), Korn \& Weyer (2003), and Nowak (2008); zonal key after Becker (1996). Abbreviations: HBS - Hangenberg Black Shale; HSS - Hangenberg Sandstone; SL - Stockum Limestone; KF - Kahlenberg Formation; ckI - costatus-kockeli Interregnum; su - sulcata; du - duplicata; ha - "hassi"; sa - sandbergi; $q u$ - quadruplicata; cr-crenulata. 
shales, some limestones, and black siliceous shales near the top (Clausen et al. 1989, Korn \& Weyer 2003, Korn 2015). This unit represents a transgression that can be globally traced (Kalvoda 1989, Becker 1993b, Kaiser et al. 2011).

\section{Material and methods}

\section{Analytical methods}

The Oese (thickness $34.2 \mathrm{~m}$; Fig. 3), Oberrödinghausen (10.1 m; Fig. 4) and Drewer (6.8 m; Fig. 5) sections were sampled in detail for magnetic susceptibility, element analysis and isotope geochemistry from the Wocklum Limestone (Upper expansa Zone) up to the base of the Kahlenberg Formation. The sections were described bed-by-bed and sampled for microfacies analysis at random stratigraphic intervals (between 0.1 and $2 \mathrm{~m}$ ).

The facies logging was supported by field gamma-ray spectrometry (GRS) logging with $0.25 \mathrm{~m}$ vertical step (Oese 71 data points, Oberrödinghausen 61 points, Drewer 41 points), with an RS-230 Super Spec portable spectrometer (Radiation Solutions, Inc., Canada) with a $2 \times 2$ ' $\left(103 \mathrm{~cm}^{3}\right)$ bismuth-germanate (BGO) scintillation detector. The assay time was set to $240 \mathrm{~s}$. The counts per second in the selected energy windows were automatically converted to concentrations of $\mathrm{K}(\%), \mathrm{U}$ (ppm) and Th (ppm) by the instrument. The computed gamma-ray (CGR), which is used as a good proxy for the sum of the terrigenous input in carbonates, was calculated from the spectral values with the formula CGR $[\mathrm{API}]=\mathrm{Th}[\mathrm{ppm}] \cdot 3.93+\mathrm{K}[\%] \cdot 16.32$ (Rider 1999).

Rock samples relieved of weathered parts (weight range 6 to $63 \mathrm{~g}$ ) for bulk magnetic susceptibility (MS) measurement were collected with $5 \mathrm{~cm}$ vertical steps in intervals with limestone-marl alternations, and in 10 to $25 \mathrm{~cm}$ steps in thick shale and sandstone intervals. MS was measured with a KLY-4 kappabridge (Agico, Czech Republic; magnetic field intensity of $300 \mathrm{Am}^{-1}$, operating frequency of $920 \mathrm{~Hz}$, sensivity of $\left.4 \cdot 10^{-8} \mathrm{SI}\right)$. Mass-specific MS data expressed in $\mathrm{m}^{3} \cdot \mathrm{kg}^{-1}$ were used. A total of $562 \mathrm{MS}$ samples (Oese: 284 ; Oberrödinghausen: 158; Drewer: 120) were measured.

The same samples as for MS measurements, together with additional samples from the Drewer Sandstone interval (parallel section Drewer-B), were analysed by energy dispersive X-ray fluorescence (XRF) with a MiniPal 4.0 (PANalytical, the Netherlands) and an Rh lamp and Peltier cooled Si PIN detector. The samples were ground to analytical fineness and poured into plastic cells with a diameter of $25 \mathrm{~mm}$ and Mylar foil bottoms. Al and $\mathrm{Si}$ signals were acquired for $300 \mathrm{~s}$ at $5 \mathrm{kV} / 400 \mu \mathrm{A}$ with a Kapton filter under He flush (99.996\% purity), K, Ti, Fe, and Mn and Fe for $200 \mathrm{~s}$ at $12 \mathrm{kV} / 200 \mu \mathrm{A}$ with a thin $\mathrm{Al}$ filter in air, and $\mathrm{Zr}$ for $500 \mathrm{~s}$ at $30 \mathrm{kV} / 200 \mu \mathrm{A}$ with an Ag filter in air. XRF data were expressed in counts per

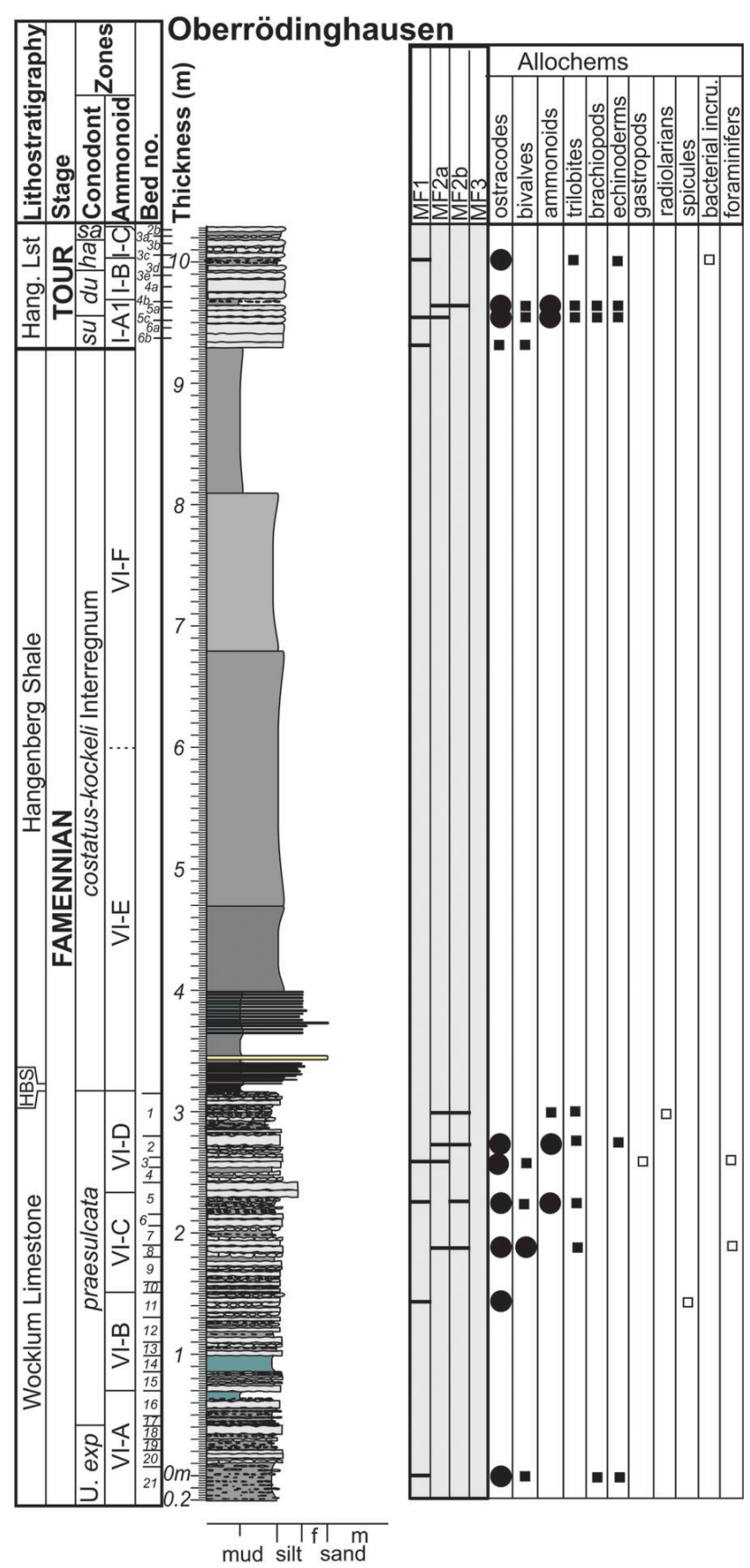

Figure 4. A stratigraphic, lithostratigraphic and sedimentological log of the Oberrödinghausen (railway cut) section. Conodont biostratigraphy based on data in Voges (1960), Kürschner et al. (1993), Korn \& Weyer (2003) and Kaiser (2005). Ammonoid biostratigraphy based on Schindewolf (1937), Vöhringer (1960), Paproth \& Streel (1970), Korn (1993), and Becker (2000); zonal key after Becker (1996). Abbreviations: HBS - Hangenberg Black Shale; HSS - Hangenberg Sandstone; SL - Stockum Limestone; U. exp - Upper expansa; su - sulcata; du-duplicata; $h$ - "hassi"; sa-sandbergi.

second (c.p.s.). The XRF proxy signal was calibrated by analysis of 11 samples by an accredited analytical laboratory in Technical University Ostrava, Czech Republic. 


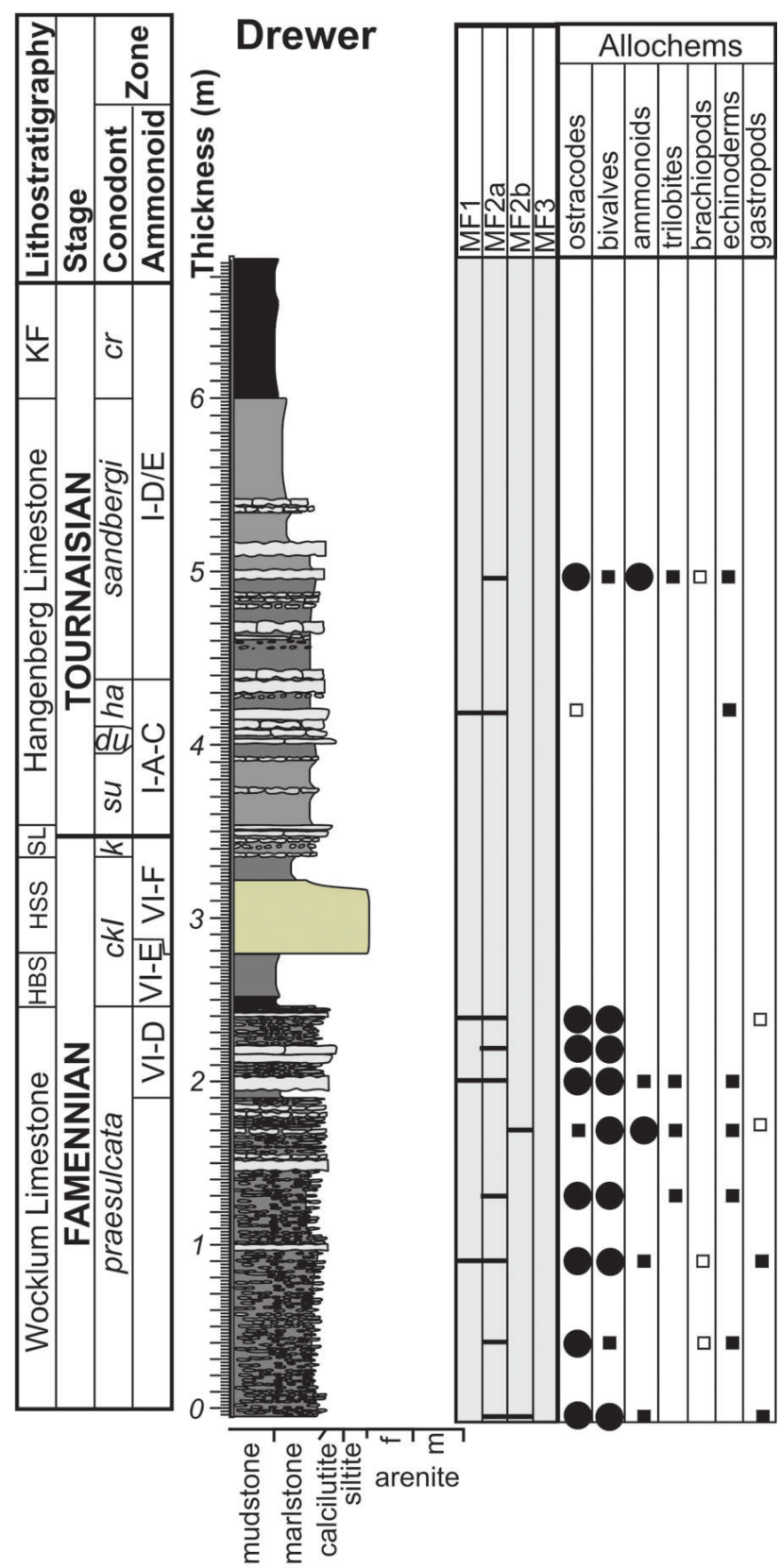

Figure 5. A stratigraphic, lithostratigraphic and sedimentological log of the Drewer section. Conodont and ammonoid biostratigraphy adopted from Clausen et al. (1989) and Korn et al. (1994); ammonoid zonal key after Becker (1996). Abbreviations: HBS - Hangenberg Black Shale; HSS - Hangenberg Sandstone; SL - Stockum Limestone; KF - Kahlenberg Formation; ckI = costatus-kockeli Interregnum; sul - sulcata; du-duplicata; ha- "hassi"; cr-crenulata.

Several milligrams of rock powder were recovered from limestone samples (preferentially homogenous micrite to very fine microsparite) from the Hangenberg Limestone for bulk carbon isotope geochemistry. The carbonate powder was treated with phosphoric acid in an on-line carbonate preparation system connected to a
Thermo Scientific DELTA V mass spectrometer. All the values were reported in \%o relative to $\mathrm{V}-\mathrm{PDB}$ by assigning a $\delta^{13} \mathrm{C}$ value of $+1.95 \%$ and a $\delta^{18} \mathrm{O}$ value of $2.20 \%$ to NSB 19. The accuracy and precision were controlled by replicate measurements of laboratory standards and were better than $\pm 0.1 \%$ o for both carbon and oxygen isotopes.

\section{Interpretative potential of petrophysical and geochemical proxies}

Element concentrations in sediments provide useful tools for palaeoenvironmental interpretation with regard to the bulk and component fluxes of detrital grains and their sources (Al, K, Th, Zr), oceanic palaeoproductivity $(\mathrm{Cu}, \mathrm{Zn}, \mathrm{Ni}$, $\mathrm{Pb}$ ), and redox conditions (U, Mn, S) (e.g., Fralick \& Kroberg 1997, Sageman \& Lyons 2005, Sliwinski et al. 2010, Bout-Roumazeilles et al. 2013).

CGR (see section "Analytical methods"), counted from the $\mathrm{K}$ and $\mathrm{Th}$ concentrations (measured by gamma-ray spectrometry), is used as siliciclastic volume indicator in carbonate successions (e.g., Rider 1999; Bábek et al. 2013; Kumpan et al. 2014a, b). The presence of $\mathrm{K}$ is tied to clay minerals, micas and feldspars, whereas Th is a constituent of clay minerals and, to a lesser extent, of heavy minerals, such as zircon and monazite (Rider 1999, Ehrenberg \& Svana 2001, Doveton \& Meriam 2004, Lüning et al. 2004). The CGR proved to be a good proxy of carbonate sedimentation rates and relative bathymetry in carbonate ramp successions (Bábek et al. 2013). Th/K ratio can be used as proxy for clay mineral association changes, when low values are typical for illite (also for K-feldspars and micas) and high values for smectite, kaolinite or chlorite (Doveton 1991).

Wide range of detrital input proxies provides XRF measuring. Aluminium, as one of the main components of clay minerals, feldspars or micas, is generally used as the main conservative proxy for siliciclastic bulk content in sediments (Sageman \& Lyons 2005) and we used an Al normalisation of terrigenous proxies to suppress the carbonate-dilution effect. Potassium, normalised by $\mathrm{Al}$, is a further convenient clay-mineral proxy (Rachold \& Brumsack 2001, Niebuhr 2005). High K/Al ratios are typical of illite, but are lower for smectite and lowest for chlorite and kaolinite, which does not contain $\mathrm{K}$ at all. Primary sources of illite are physically weathered rocks rich in muscovite and K-feldspars (Griffin et al. 1968). Smectite is a characteristic product of moderate chemical weathering in a humid climate, whereas enhanced weathering produces kaolinite. The particles of smectite are smaller than those of illite and kaolinite and are transported for longer distances to the basin (Rider 1999, Doveton 1991). Zirconium, titanium or rubidium, on the other hand, are predominantly related to heavy minerals (zircon, titanite, etc.), 
which are common components of relatively coarsergrained (mainly silt-sized) siliciclastic fractions and their enrichment is therefore generally interpreted as coarser siliciclastic presence in fine-grained sediments (Fralick \& Kronberg 1997, Schnetger et al. 2000). Zr/Al was chosen as grain-size proxy in this study. High $\mathrm{Zr} / \mathrm{Al}$ values may reflect sedimentation during times of increased siliciclastic input into the deeper basin, both via fluvial and aeolian pathways (Pye 1987, Sageman \& Lyons 2005). Zr/Al can also be used for approximation of distance to a siliciclastic source, when high values reflect a more proximal position.

Uranium, which was measured by gamma-ray spectrometry in this study, is highly soluble under oxic to suboxic conditions and is fixed to the sediment with buried organic matter in a reducing environment. On the other hand, various detrital minerals, such as zirconium, monazite or uraninite, can also contribute to the CGR uranium signal. Because thorium is a redox conservative element, it is used for the normalisation of uranium. High values of U/Th (or low Th/U) ratios are generally considered as reflecting a detrital independent U-enrichment, related to hypoxic to anoxic conditions (Adams \& Weaver 1958, Calvert \& Pedersen 1993, Jones \& Manning 1994, Doveton \& Merriam 2004, Lüning et al. 2004). U/Th ratio lower than 0.75 indicates oxic conditions, whereas values between $0.75-1.25$ indicate dysoxic conditions and higher than 1.25 anoxia (Jones \& Manning 1994). However, U/Th signal from the weathered sections can be affected by oxidation and migration of $\mathrm{U}$ in aqueous solutions (e.g. Pollack et al. 2009), whereas Th is conservative during weathering. 95\% signal of GRS measurement comes from $25 \mathrm{~cm}$ radius hemisphere (e.g. Doveton 1994, Hladil et al. 2006) and therefore considerable large volume of unweathered rock is measured. Although the measured U concentrations are depleted in weathered parts, primary increasing/decreasing trends of $\mathrm{U} / \mathrm{Th}$ or $\mathrm{Th} / \mathrm{U}$ ratio are preserved. Reducing environments are also characterised by sulphide formation, e.g., by Fe-oxide conversion to sulphides, in particular to pyrite. The degree of pyritisation can be inferred from the S enrichment (e.g., Rimmer 2004). Another elemental redox proxy employed is manganese, which is extremely mobile during early diagenesis in reduced marine sediments (divalent $\mathrm{Mn}$ ), whereas immobile tri- and tetravalent $\mathrm{Mn}$ is formed in oxidising environments. Higher Mn values are typical of the oxidising front in sediment (Thomson et al. 1995, Schnetger et al. 2000, Maynard 2005, Roy 2006, Tribovillard et al. 2006, Rodríguez-Tovar \& Reolid 2013).

The heavy metals $\mathrm{Cu}, \mathrm{Ni}, \mathrm{Zn}$, and $\mathrm{Pb}$ may be swept from marine water as sulphides or were adsorbed to organic matter (Dean 2007). They are therefore sensitive to redox conditions and/or palaeoproductivity rates. Copper is particularly immobile under reducing conditions (Shaw et al. 1990, Schnetger et al. 2000, Laurent et al. 2006). We used $\mathrm{Cu}, \mathrm{Ni}, \mathrm{Zn}$ and $\mathrm{Pb}$ sums as a proxy for redox and palaeoproductivity changes in this study; the association of these elements is revealed by their close relationship in principal component analysis (PCA).

MS is normally used as proxy for siliciclastic content in carbonates (e.g. Crick et al. 1997, Elwood et al. 1999). Low MS values reflect regressions whereas high values are characteristic for transgressions and high-stands in deepmarine carbonate successions, which is opposite to interpretations of shallow-marine MS trends. It is caused by resedimentation of carbonates to deeper basins during regressions, which dilutes clastic content (e.g. Bábek et al. 2010, Da Silva et al. 2010).

\section{Results}

\section{Lithology of the sections}

The Wocklum Limestone represents an alternation of predominantly dark to light grey nodular limestones (1 to $15 \mathrm{~cm}$ thick) with marls and shales ( 0.5 to $50 \mathrm{~cm}$ thick). The marls and shales are dark greyish at Drewer (Fig. 5) and greenish to greyish at Oberrödinghausen (Fig. 4) and at Oese (Fig. 3). At Oese reddish shales and marls intercalate episodically between greyish to reddish limestones (1.7 to $1.9 \mathrm{~m}$ and 2.75 to 5.2 , respectively), as the result of more advanced oxidative weathering processes. Two reddish metabentonite layers, a few centimetres thick, also occur at Oese (Fig. 3; 4.6 and 31.61 m; see Korn \& Weyer 2003). Limestone-marl alternations reveal a distinctive cyclicity in all of the studied sections. The ideal cycle is 20 to $30 \mathrm{~cm}$ thick and starts with platy nodular limestone overlain by intervals of shale with limestone nodules, and topped by shale (Korn \& Weyer 2003).

Limestones are in places rich in macrofauna, mainly cephalopods, bivalves, brachiopods (rhynchonellids), trilobites, and fragmented crinoids. Compressed bivalve and cephalopod shells occur in some marls and shales. Common bioturbation fabrics were observed in the limestones. The richest Wocklumeria faunas occur at the top.

The Drewer Sandstone (praesulcata Zone) of Drewer is a thin $(30 \mathrm{~cm})$ intercalation of laminated, calcareous, mica-rich siltstone just below the top of the Wocklum Limestone. It is the type level of Postclymenia evoluta (Korn 1988), which underlines its hemipelagic depositional setting. Pyrite accumulations occur from the Drewer Sandstone to the HBSE base.

The top of the Wocklum Limestone (praesulcata Zone) is sharply overlain by Hangenberg Black Shale (basal costatus-kockeli Interregnum) comprising black shales $(6 \mathrm{~cm})$ and fissile dark greyish shale $(25 \mathrm{~cm})$ with abundant calcite veins at Drewer (Fig. 5). At Oese (Fig. 3) and Oberrödinghausen (Fig. 4), only thin layers $(1$ to $6 \mathrm{~cm}$ ) of 

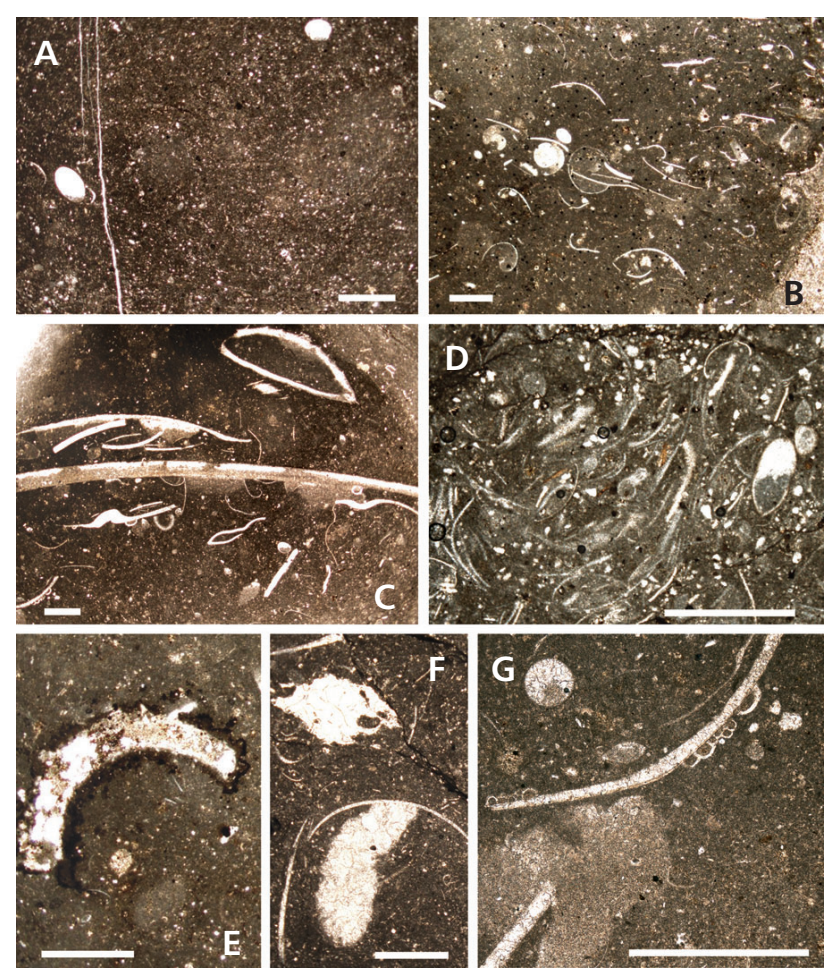

Figure 6. Microphotographs (PPL) of documented microfacies. For detailed information see section "Microfacies". Scale bar $1 \mathrm{~mm}$. - A - lime mudstone with ostracodes and silty quartz (MF1); Wocklum Limestone, Drewer, $-0.2 \mathrm{~m}$. $\mathrm{B}$ - wackestone with ammonoids and bivalves (MF2a); Wocklum Limestone, Oese, $5.6 \mathrm{~m}$. $\bullet \mathrm{C}$ - floatstone with ammonoids, brachiopods, bivalves and trilobites (MF2b); Wocklum Limestone, Oberrödinghausen, $1.9 \mathrm{~m} \cdot \bullet \mathrm{D}$ - packstone with ostracodes, ammonoids and bivalves (MF3); Hangenberg Limestone, Oese, $31.5 \mathrm{~m}$. - E - ferruginous bacterial incrustation; Wocklum Limestone, Oese, $5.7 \mathrm{~m}$. $\cdot \mathrm{F}$ - burrows infilled by sparry calcite; Wocklum Limestone, Drewer, $-0.2 \mathrm{~m} . \cdot \mathrm{G}-$ epibionts (agglutinating foraminifer Tolypammina?) encrusting fragment of ammonoid; Wocklum Limestone, Oberrödinghausen, $1.9 \mathrm{~m}$.

Fe-rich (due to oxidized pyrite) black shales are developed in the lithostratigraphic and biostratigraphic levels correlative with the HBS and yielded squashed cymaclymeniid ammonoids (Postclymenia evoluta). Small black limestone nodules with ammonoids are intercalated in the uppermost part of HBS at Drewer (Korn 1991).

The HBS interval is overlain by the Hangenberg Shale (costatus-kockeli conodont Interregnum) in the Oberrödinghausen (6.1 m thick; Fig. 4) and Oese sections (5.9 m; Fig. 3), which are dark grey shale with Fe oxides (oxidized pyrite) and a variable content of silt and sand fractions (mainly muscovite and quartz). The shales contain laminae and thin beds (less than $2 \mathrm{~cm}$ thick) of siltstones to very fine-grained sandstones with common horizontal lamination and less frequent ripple cross-lamination. The shale is more calcareous in the upper part. Compressed shells of bivalves (Guerichia sp.) are abundant in numerous horizons and less common are goniatites (Paproth \& Streel 1970; new specimens), which are the oldest Acutimitoceras (Stockumites).

About $45 \mathrm{~cm}$ thick dark greyish fine-grained graded calcareous sandstone to siltstone of the Hangenberg Sandstone Member (higher costatus-kockeli Interregnum), is developed in the Drewer section on top of the Hangenberg Black Shale (Fig. 5). At Oese (Fig. 3), the sandstone member overlies the Hangenberg Shale and is much thicker ( $c a$ $18 \mathrm{~m}$ ) than at Drewer. The Hangenberg Sandstone interval is composed of quartz- and mica-rich, massive or normally graded, medium- to fine-grained sandstones alternating with siltstones and heterolithic facies (flaser siltstones with mudstones). A sheet-like and thick-bedded geometry is characteristic of sandstone layers, which usually have sharp bases with load structures (and mudrock intraclasts) at both sections. Positive gradation, horizontal and cross-lamination and wavy bedding were observed as well. Plant debris (leaves, stems, etc.) is abundant in siltstones and mainly in the heterolithic facies at Oese (Fig. 3). At Oberrödinghausen (Fig. 4), the sandstone member is not developed and only two thin (thickness $\sim 3 \mathrm{~cm}$ ) sandstone layers occur near the base of the Hangenberg Shale.

The overlying limestone unit includes the Stockum Limestone (kockeli to basal sulcata zones) at its base at Oese (Fig. 3) and Drewer (Fig. 5), which is characterised by the occurrence of Lower and Upper Protognathodus conodont faunas (Alberti et al. 1974, Clausen et al. 1989, Luppold et al. 1994) and Acutimitoceras (Stockumites) goniatite faunas (Korn et al. 1994, Korn \& Weyer 2003). It is lacking in a minor unconformity at Oberrödinghausen (Bless et al. 1993). The overlying Hangenberg Limestone (main sulcata to quadruplicata Zones) is $2.8 \mathrm{~m}$ thick at Drewer (Fig. 5), $2.7 \mathrm{~m}$ at Oese (Fig. 3), and $1 \mathrm{~m}$ (incomplete) at Oberrödinghausen (Fig. 4). It consists of an alternation of limestones, grey shales or marlstones in all studied sections. Metabentonite layer was found at Oese (31.6 m; Fig. 3; Korn \& Weyer 2003). The Hangenberg Limestone yielded an abundant cephalopod, bivalve, brachiopod and trilobite assemblage (Gattendorfia faunas). Marly shales with scattered limestone nodules occur in the upper part of the member. The Hangenberg Limestone is overlain by the Kahlenberg Formation (Lower crenulata Zone; Figs 3-5), represented by black shales in the lower part (thickness 0.5 to $1 \mathrm{~m}$ ) and by siliceous black shales with phosphorite nodules in the upper part (thickness $0.5 \mathrm{~m}$ ).

\section{Microfacies}

Carbonate microfacies are relatively monotonous in the studied sections (Fig. 6). Silty and bioclastic lime-mudstones (MF1; Fig. 6A) and bioclastic wackestones (MF2a; Fig. 6B) are the most common types. Less frequent are wackestones with large scattered "floating" bioclasts, 
Table 1. Median (M) and standard deviation (sd) of gamma-ray spectrometry values sorted by lithostratigraphic members and studied sections; $\mathrm{n}$ - number of measurements.

\begin{tabular}{|c|c|c|c|c|c|c|c|c|c|c|}
\hline & & \multirow{2}{*}{$\mathrm{n}$} & \multicolumn{2}{|c|}{ CGR (API) } & \multicolumn{2}{|c|}{$\mathrm{K}(\%)$} & \multicolumn{2}{|c|}{$\mathrm{U}(\mathrm{ppm})$} & \multicolumn{2}{|c|}{ Th (ppm) } \\
\hline & & & M & sd & M & sd & M & sd & M & sd \\
\hline \multirow[t]{3}{*}{ Wocklum Limestone } & Drewer & 17 & 91.1 & 8.1 & 3.0 & 0.3 & 3.0 & 1.3 & 10.5 & 1.1 \\
\hline & Ober-Röding. & 19 & 97.2 & 9.7 & 3.5 & 0.4 & 2.1 & 0.6 & 11.0 & 1.1 \\
\hline & Oese & 29 & 92.4 & 14.2 & 3.5 & 0.5 & 1.8 & 0.7 & 10.5 & 1.8 \\
\hline \multirow[t]{3}{*}{ Hangenberg Black Shale } & Drewer & 4 & 127.1 & 9.9 & 4.2 & 0.3 & 8.0 & 0.8 & 15.1 & 1.5 \\
\hline & Ober-Röding. & 1 & 138.4 & - & 4.8 & - & 4.2 & - & 15.3 & - \\
\hline & Oese & 1 & 146.8 & - & 5 & - & 4.4 & - & 16.6 & - \\
\hline \multirow[t]{2}{*}{ Hangenberg Shale } & Ober-Röding. & 32 & 143.8 & 14.0 & 5.1 & 0.5 & 3.7 & 0.7 & 15.8 & 1.8 \\
\hline & Oese & 20 & 135.4 & 11.6 & 4.6 & 0.4 & 2.9 & 0.5 & 15.5 & 1.6 \\
\hline \multirow[t]{2}{*}{ Hangenberg Sandstone } & Drewer & 4 & 131.0 & 3.4 & 4.0 & 0.2 & 5.1 & 1.6 & 16.8 & 0.8 \\
\hline & Oese & 27 & 97.65 & 19.0 & 3.3 & 0.8 & 2.6 & 0.6 & 11.5 & 1.7 \\
\hline \multirow[t]{3}{*}{ Hangenberg Limestone } & Drewer & 13 & 114.7 & 18.6 & 3.8 & 0.7 & 3.4 & 1.8 & 14.2 & 1.9 \\
\hline & Ober-Röding. & 4 & 97.3 & 23.0 & 3.3 & 0.7 & 1.8 & 0.7 & 10.6 & 1.6 \\
\hline & Oese & 8 & 88.2 & 22.2 & 2.8 & 0.3 & 1.9 & 0.3 & 10.3 & 1.1 \\
\hline \multirow[t]{3}{*}{ Kahlenberg Formation } & Drewer & 3 & 133.6 & 7.7 & 4.5 & 0.2 & 11.2 & 0.8 & 15.3 & 1.1 \\
\hline & Ober-Röding. & 5 & 100.7 & 11.8 & 3.5 & 0.7 & 4.4 & 1.4 & 9.5 & 1.8 \\
\hline & Oese & 6 & 134.8 & 30.1 & 4.6 & 1.1 & 5.2 & 1.4 & 16.7 & 3.5 \\
\hline
\end{tabular}

which are texturally close to floatstones (MF2b; Fig. 6C). Very rare are bioclastic wacke-packstones (MF3; Fig. 6D), which occur in small bioclastic "nests". These end-member microfacies change both in lateral and vertical direction and are tied by transitional facies. Neomorphic recrystallisation and dolomitisation are common in places, mainly linked with burrows. Authigenic euhedral pyrite crystals are abundant at several levels and occur both within the matrix, inside bioclasts or on their surface. Pressure dissolution is ubiquitous, with common microdolomite along opaque dissolution seams. Bioclasts are not micritised and are predominantly recrystallized (except trilobites and brachiopods). The main bioclast types are represented by ostracodes, cephalopods (ammonoids) and thin-shelled bivalves. Trilobites are common, whereas crinoids, gastropods, conodonts, sponge spicules and brachiopods are scarcely scattered in thin sections. Rarely spherical allochems were observed, which resemble radiolarian ghosts. Ferruginous bacterial bioclasts incrustations (Fig. 6E) and encrusting epibionts (agglutinating foraminifer Tolypammina?) cemented on the surface of large bioclasts (Fig. 6G) were found in two levels in the Oberrödinghausen section (Fig. 4). Angular to subangular quartz grains (fine sand to silty fraction) and micas (predominantly muscovite) are present in variable concentrations in the studied samples (ranging from rare and scattered to very abundant grains with microfacies transition to calcareous siltstones). The sorting of bioclasts is very poor and the orientation is usually random. Only in two samples, bioclasts oriented parallel to bedding planes have been ob- served. Geopetal infills are common, especially within ostracod and cephalopod shells, usually parallel to bedding. Chaotic bioturbation is evident in all samples, as well as more distinctive burrows, sometimes infilled by sparry calcite (Fig. 6F).

The mixed siliciclastic-carbonate microfacies of the marly interlayers involve bioclastic mudstones to siltstones, which are predominantly mud-dominated with abundant quartz and muscovite. Crinoids, trilobites, ostracodes, spicules or bivalves are common in places. Relatively sharp and irregular dissolution seam-based boundaries between the carbonate microfacies and mudstones and siltstones are common, but gradual transitions were also observed.

Siliciclastic sediments comprise medium- to finegrained quartzose sandstones to quartzose siltstones with well sorted angular to subangular grains. Quartz is a dominant component, which is accompanied by abundant muscovite oriented parallel to bedding planes. Scattered plant debris, bioclasts (ostracodes?) and authigenic pyrite are common. Lamination controlled by grain size changes and ripples have been observed.

\section{Gamma-ray spectrometry}

The measured field gamma-ray spectrometry data display moderate to relatively high CGR values (71 to 167 API) and variable content of $\mathrm{K}, \mathrm{U}$ and $\mathrm{Th}$ and their ratios (Table 1). Statistical correlation of the GRS dose rate 


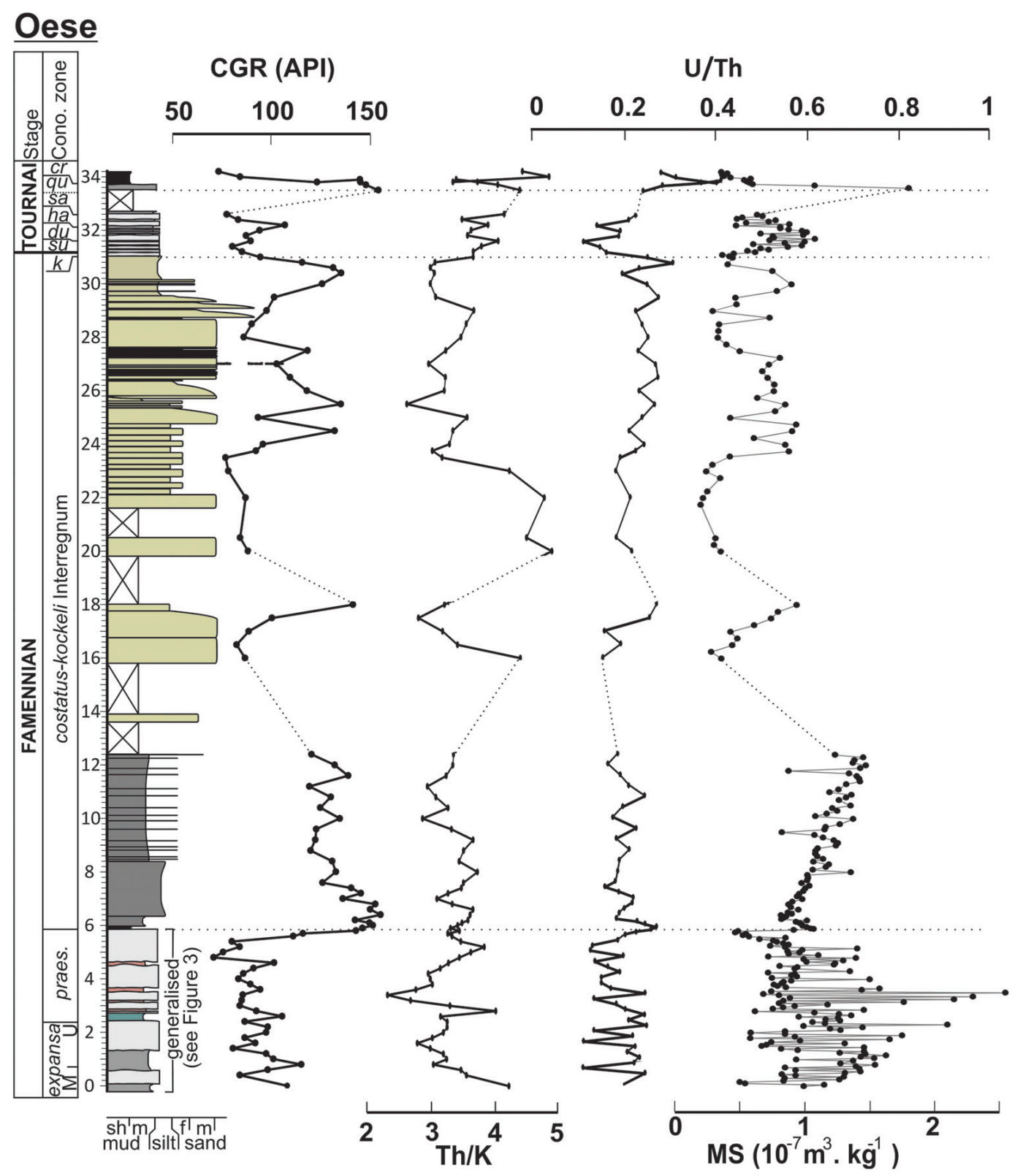

Figure 7. Oese. Curves of selected petrophysical proxies. Abbreviations of conodont zones: praes. - praesulcata; $k$ - kockeli; su - sulcata; du-duplicata; ha - "hassi"; sa-sandbergi; qu-quadruplicata; cr-crenulata.

(nGy. $\mathrm{kg}^{-1}$ ) with all measured radioactive elements reveals that the dominant source of radioactivity is potassium (Oese $\mathrm{R}^{2}=0.90$; Oberrödinghausen $\mathrm{R}^{2}=0.96$; Drewer $\mathrm{R}^{2}=$ 0.84 ), followed by thorium (Oese $R^{2}=0.90$; Oberrödinghausen $\mathrm{R}^{2}=0.90$; Drewer $\mathrm{R}^{2}=0.70$ ), and uranium (Oese $\mathrm{R}^{2}=0.70$; Oberrödinghausen $\mathrm{R}^{2}=0.60$; Drewer $\mathrm{R}^{2}=0.81$ ). The $\mathrm{K}$ and Th concentrations are well to moderately correlated (Oese $\mathrm{R}^{2}=0.73$; Oberrödinghausen $\mathrm{R}^{2}=0.60$; Drewer $\left.\mathrm{R}^{2}=0.88\right)$ and the $\mathrm{K}: \mathrm{U}\left(\right.$ Oese $\mathrm{R}^{2}=0.44$; Oberrödinghausen $R^{2}=0.45$; Drewer $R^{2}=0.46$ ) as well as $T h: U$ (Oese $\mathrm{R}^{2}=0.57$; Oberrödinghausen $\mathrm{R}^{2}=0.33$; Drewer $\mathrm{R}^{2}=$ $0.29)$ correlation coefficients are much lower.
The vertical distribution of $\mathrm{CGR}$ and U/Th ratios shows distinctive and similar patterns in all studied sections and it is possible to trace several correlative horizons (see "Regional correlation"). Moderate CGR values were measured in the Wocklum Limestone (Table 1). The most significant increase in CGR values occurs close to the transition from Wocklum Limestone to the Hangenberg Black Shale in all sections in the uppermost praesulcata Zone (sensu Kaiser et al. 2009; Figs 7-9). Generally higher CGR values are typical for the Hangenberg Shale and Sandstone (costatus-kockeli Interregnum) (Table 1, Figs 7-9). The CGR values of the Hangenberg 


\section{Oberrödinghausen}

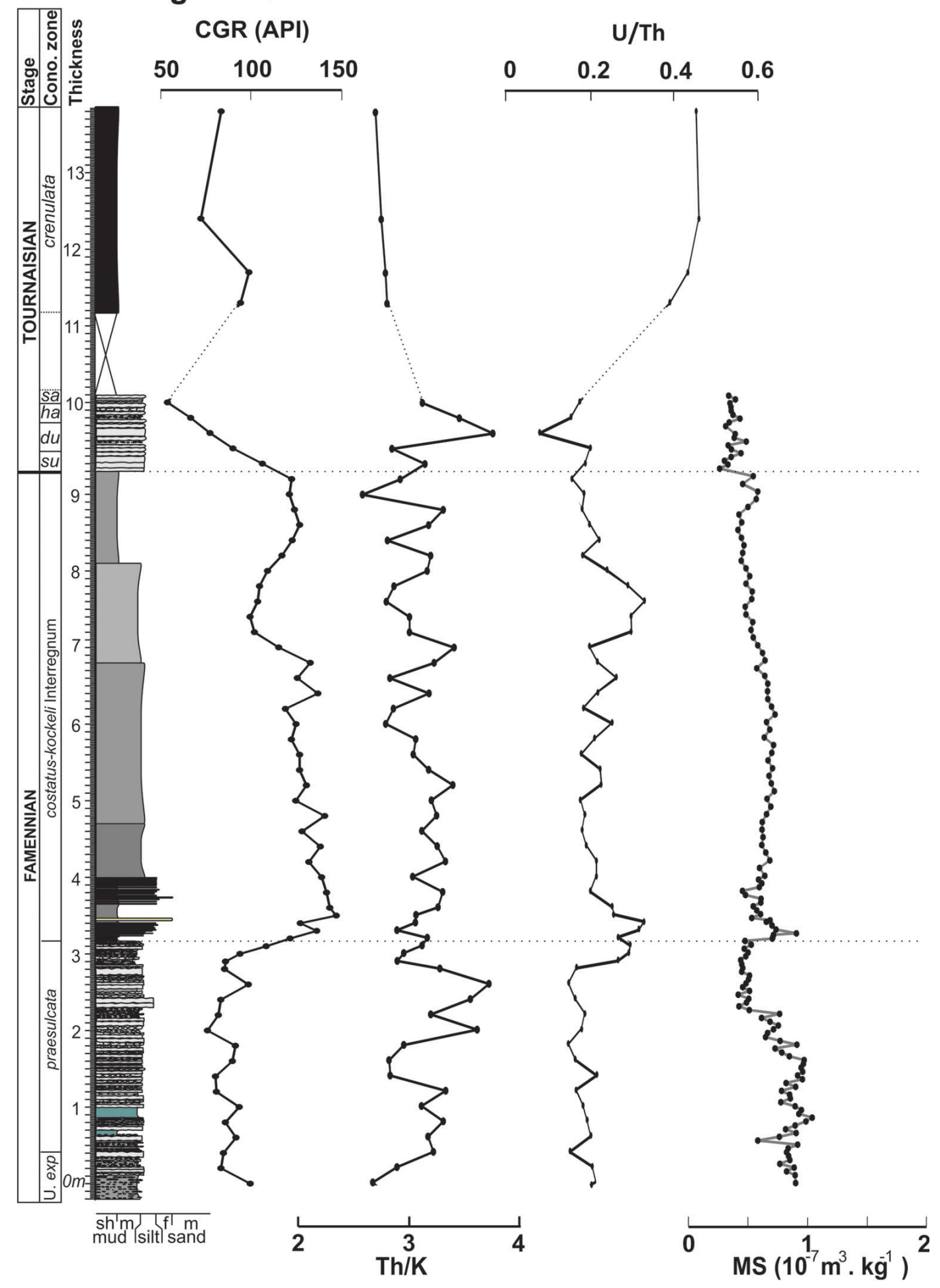

Figure 8. Oberrödinghausen. Curves of selected petrophysical proxies. Abbreviations of conodont zones: U. exp. - Upper expansa; su - sulcata; du-duplicata; ha - "hassi"; sa-sandbergi; qu-quadruplicata; cr-crenulata.

Shale at Oberrödinghausen are high, with a peak $25 \mathrm{~cm}$ above its base, where thin beds and laminae of sandstones occur. The Hangenberg Sandstone at Drewer is character- ised by high CGR, whereas the thick sandstone sequence at Oese reveals fluctuations between relatively low to high values. CGR decrease in the lower part of the Hangenberg 


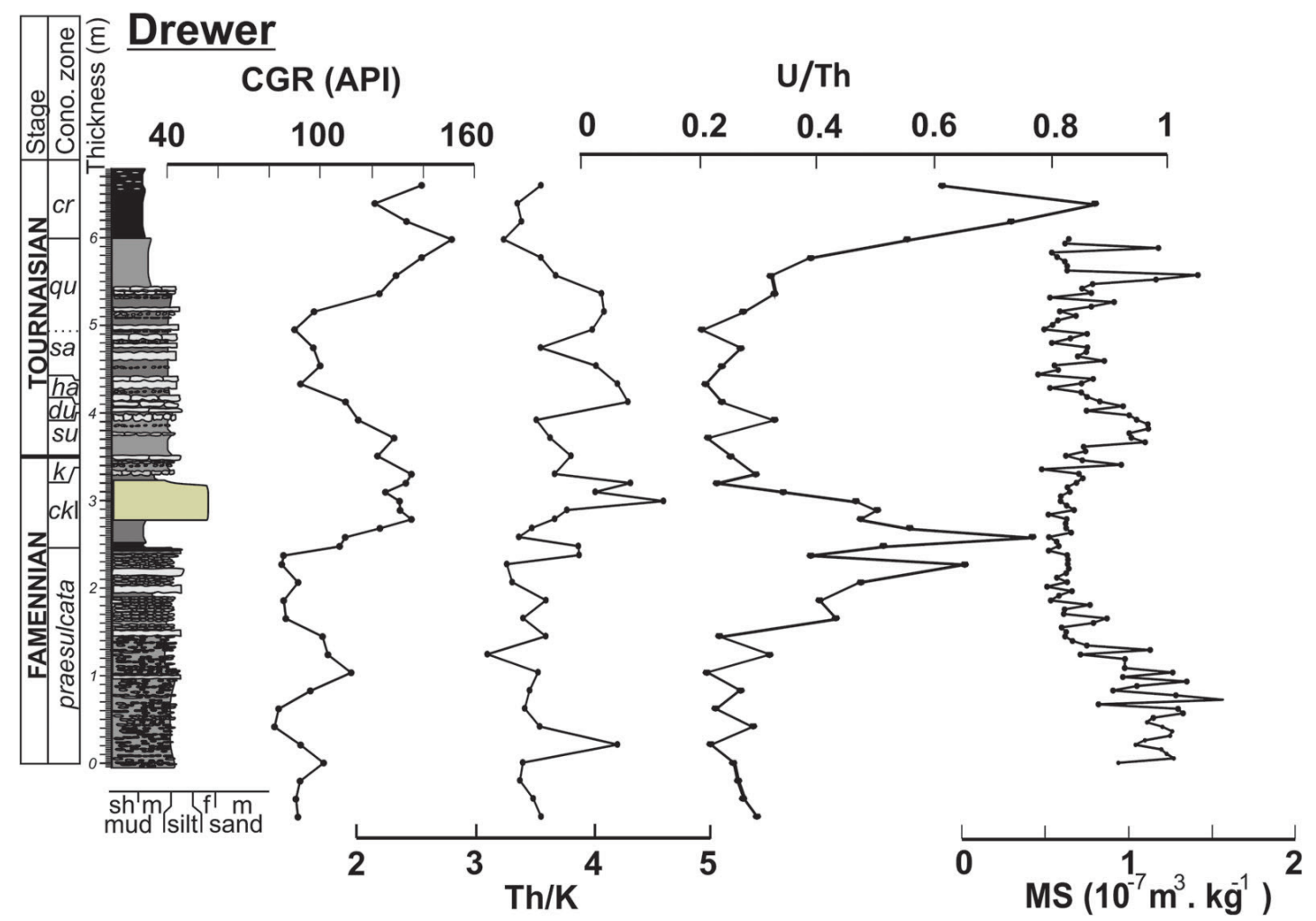

Figure 9. Drewer. Curves of selected petrophysical proxies. Abbreviations of conodont zones: ckI - costatus-kockeli Interregnum; $k-k o c k e l i$; su-sulcata; du-duplicata; ha - "hassi"; sa - sandbergi; qu-quadruplicata; $c r$ - crenulata.

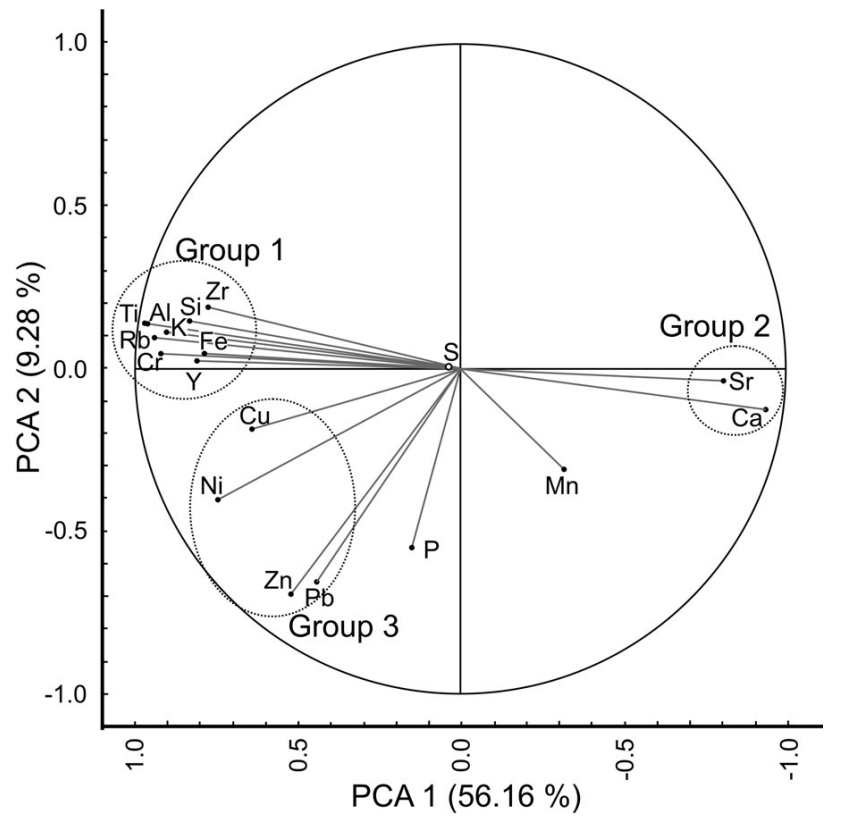

Figure 10. Principal component analysis of the XRF data from the studied sections.

Limestone and rise again in its upper part (in the sandbergi Zone).

U/Th values from Drewer (average values 0.34) are generally higher than values from Oese (0.21) and Oberrödinghausen (0.23). The U/Th curves begin with a decreasing trend in the lower part of the studied Wocklum Limestone followed by a sharp increase in its upper or uppermost part (praesulcata Zone; Oese: at $\sim 5.0 \mathrm{~m}$, Oberrödinghausen: at $\sim 2.8$, Drewer: at $\sim 1.0 \mathrm{~m}$; Figs $7-9$ ). U/Th positive peak occurs just below and in the Hangenberg Black Shale (just below and at the base of the costatus-kockeli Interrgenum; Drewer 0.77, Oese 0.27, Oberrödinghausen 0.34). Low U/Th values in the Hangenberg Black Shale at Oese and Oberrödinghausen can be explained by partial $U$ depletion during weathering (see "Interpretative potential of petrophysical and geochemical proxies"). Moreover, due to the low thickness of the black shales was GRS signal affected by a radiation of the underlying Wocklum Limestone and the overlying Hangenberg Shale. Lower U/Th ratio is typical for the Stockum and Hangenberg Limestone and U/Th maxima for the overlying Kahlenberg Formation (at Drewer 0.88).

\section{Magnetic susceptibility}

Patterns of the MS and siliciclastic proxies (CGR, Zr/Al, $\mathrm{K} / \mathrm{Al}$ ) curves are not correlatable, which reveals, that the MS signal is not driven by siliciclastic content. It implies 


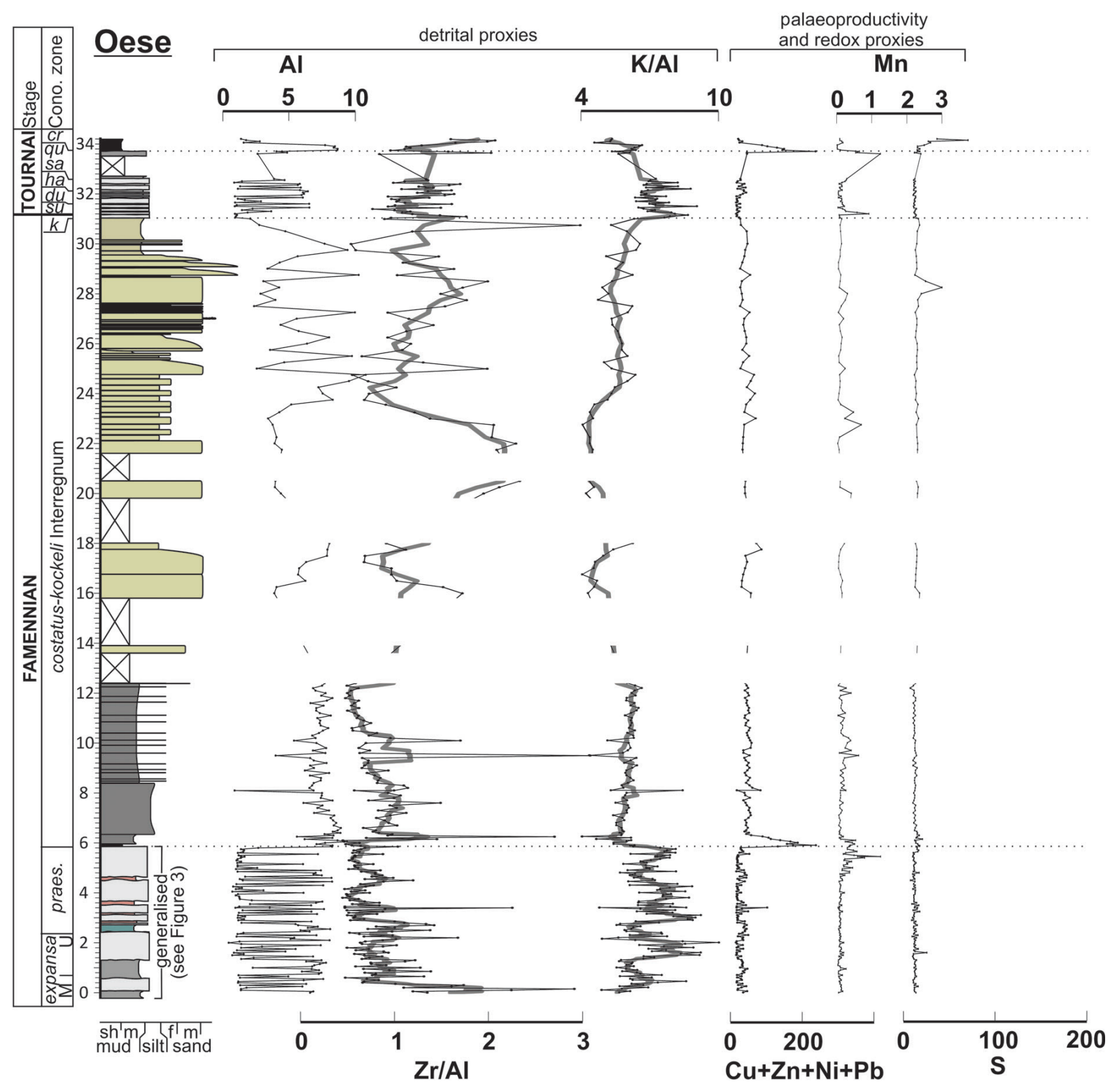

Figure 11. Oese. Curves of selected geochemical proxies for detrital input, palaeoproductivity, and redox conditions. Abbreviations of conodont zones: praes. - praesulcata; $k$-kockeli; su-sulcata; du-duplicata; ha- "hassi”; sa-sandbergi; qu-quadruplicata; cr-crenulata.

that the generally used interpretative approach (see "Interpretative potential of petrophysical and geochemical proxies") is not applicable to our MS data. However, trends of the MS stratigraphy can be correlated between the studied sections in the Wocklum Limestone (Figs 7-9). The first correlative interval (Upper expansa to praesulcata Zone) reveals a slightly increasing trend, the second interval (praesulcata Zone) is characterised by a decrease, and the uppermost part of the Wocklum Limestone (top of the praesulcata Zone) shows a very uniform aggradational pattern. MS values increase sharply to peak at the base of Hangenberg
Black Shale (basal costatus-kockeli Interrgenum) at Oberrödinghausen and Oese and drops higher up the section, but are uniform in the whole Hangenberg siliciclastic unit at Drewer. The Hangenberg siliciclastic unit (costatuskockeli Interregnum) in the Oese and Oberrödinghausen sections can be divided into a lower part with slightly rising values (Hangenberg Shale of Oese) and an upper part with decreasing or low values. The MS signature of the Hangenberg Limestone is characterised by an increasing trend at the base (sulcata Zone), a decreasing trend within the upper part of the member (sandbergi Zone) and a rising trend 


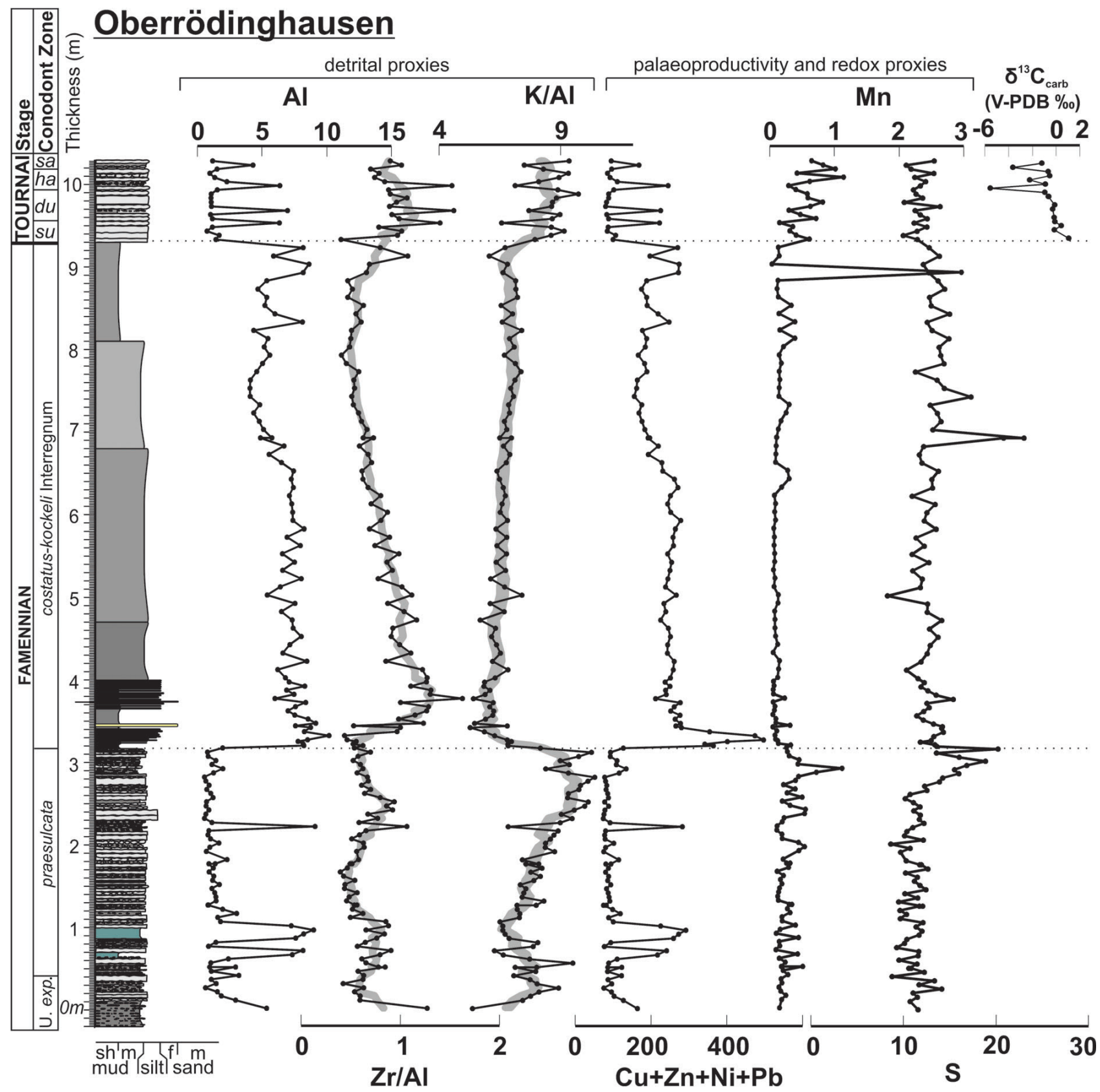

Figure 12. Oberrödinghausen. Curves of selected geochemical proxies for detrital input, palaeoproductivity, redox conditions and inorganic carbon isotopes. Abbreviations of conodont zones: U. exp. - Upper expansa; su - sulcata; du -duplicata; ha - "hassi"; sa - sandbergi; qu - quadruplicata.

towards the Kahlenberg Formation at Drewer and Oese. On the other hand, MS decreases at the base of the Hangenberg Limestone at Oberrödinghausen.

\section{Element geochemistry}

In principal component analysis (PCA), clusters of the typically terrigenous elements $\mathrm{Al}, \mathrm{Si}, \mathrm{K}, \mathrm{Zr}, \mathrm{Ti}, \mathrm{Rb}$, and $\mathrm{Y}$ (Group 1; Fig. 10) have highly positive scores on PC1 and slightly positive scores on PC2, as opposed to $\mathrm{Ca}$ and $\mathrm{Sr}$ (Group 2; Fig. 10), elements tied to carbonates, which have highly negative scores on PC1 and slightly negative scores on PC2. The highly negative statistical correlation between Groups 1 and 2 is a consequence of the dilution effect of terrigenous materials by calcium carbonate. The third cluster (Group 3; Fig. 10) have medial positive scores on PC1 and low to medium negative scores on PC2 and involve the trace metals $\mathrm{Ni}, \mathrm{Cu}, \mathrm{Zn}$, and $\mathrm{Pb}$, which are commonly used as palaeoproductivity and redox proxies (see Interpretative 

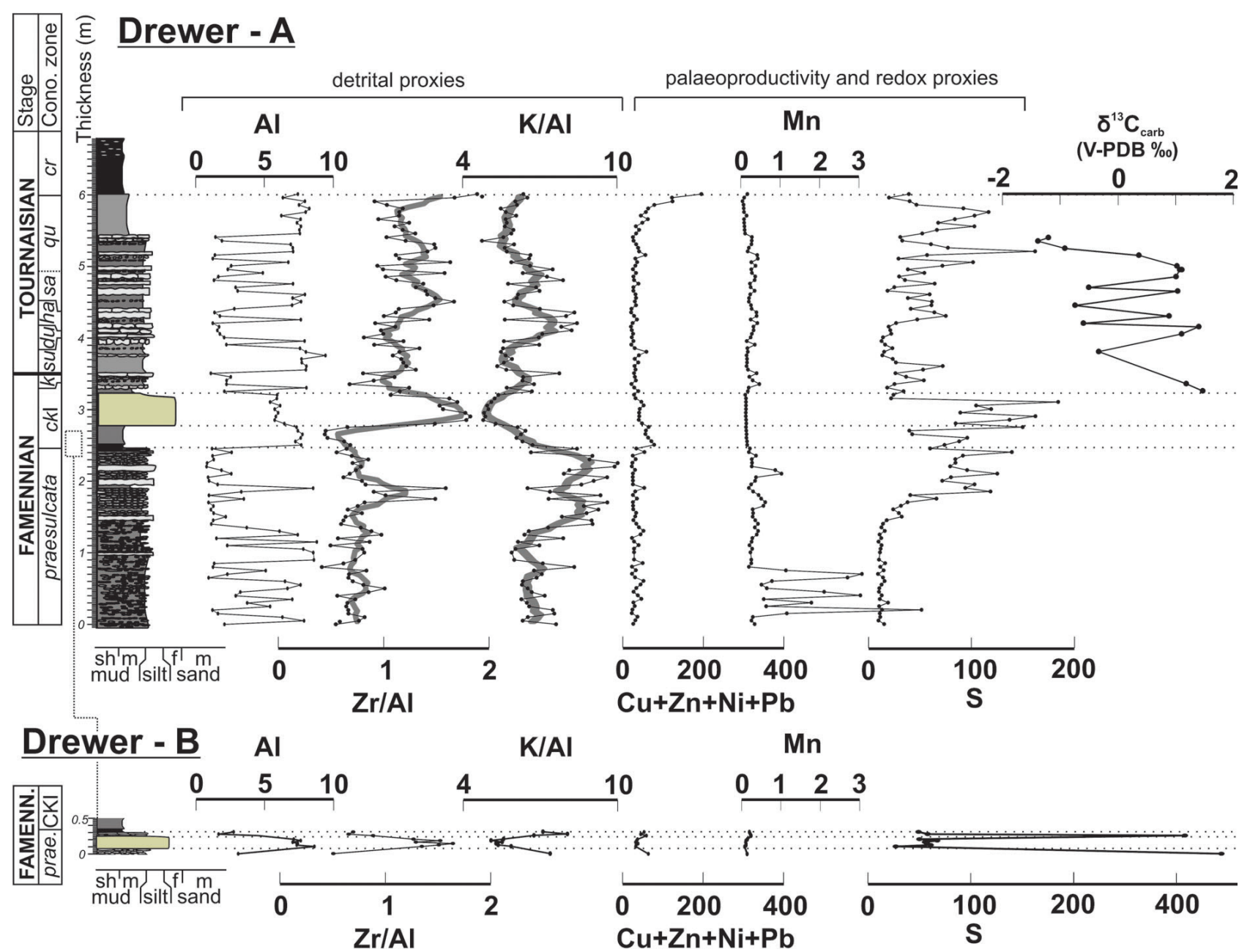

Figure 13. Drewer. Curves of of selected geochemical proxies for detrital input, palaeoproductivity, redox conditions and inorganic carbon isotopes. Abbreviations of conodont zones: ckI - costatus-kockeli Interregnum; $k$ - kockeli; su - sulcata; du - duplicata; ha - "hassi"; sa - sandbergi; qu-quadruplicata; cr-crenulata.

potential of petrophysical and geochemical proxies). Mn, S and $\mathrm{P}$ remain outside those clusters because of poor statistical correlations with other elements (Fig. 10).

Vertical changes of several elemental proxies revealed trends and/or cyclicity, which were successfully correlated between the studied sections (see "Regional correlation"). Marked cyclicity is visible on the $\mathrm{Zr} / \mathrm{Al}$ curve of the Wocklum Limestone in all studied sections (Figs 11-13). The thickness of the cycles varies from $1.2 \mathrm{~m}$ to $\sim 1.5 \mathrm{~m}$. This may indicate that the cycles had an equal periodicity and that they were driven by the same mechanism. Minima and maxima of the $\mathrm{Zr} / \mathrm{Al}$ were used for correlative chemostratigraphic tieline plotting (see "Regional correlation"). Two uppermost cycles of the Wocklum Limestone can be correlated between all studied sections. However, a base of the first cycle seems to be diachronous from a biostratigraphic point of view. Its position is at the base of the praesulcata Zone at Oese, but just at the top of the Upper expansa Zone at Oberrödinghausen (the base of the first cycle was not reached at Drewer). It can be explained by biostratigraphical difficulties, because establishing a precise horizon for the base of the praesulcata Zone is problematic due to the rare occurrence of the index conodont Siphonodella praesulcata (e.g. Kaiser et al. 2009).

The K/Al ratios are generally high in limestones and low in shales and sandstones. A marked drop coincides with the base of the Hangenberg Black Shale (basal costatus-kockeli Interregnum). Along with the marked CGR increase in values, this drop in $\mathrm{K} / \mathrm{Al}$ is the most distinctive correlative pattern in the studied sections. The $\mathrm{K} / \mathrm{Al}$ curve shows cyclicity of two orders in the Wocklum Limestone. Cycles of higher order have 20 to $30 \mathrm{~cm}$ thickness and can be correlated with individual limestone-marl cycles (see section "Cyclicity"), which can be instructively demonstrated by a comparison of cycles in the K/Al and the "carbonate" curve for Oberrödinghausen (Fig. 14) introduced by Korn \& Weyer (2003). The thickness of the 

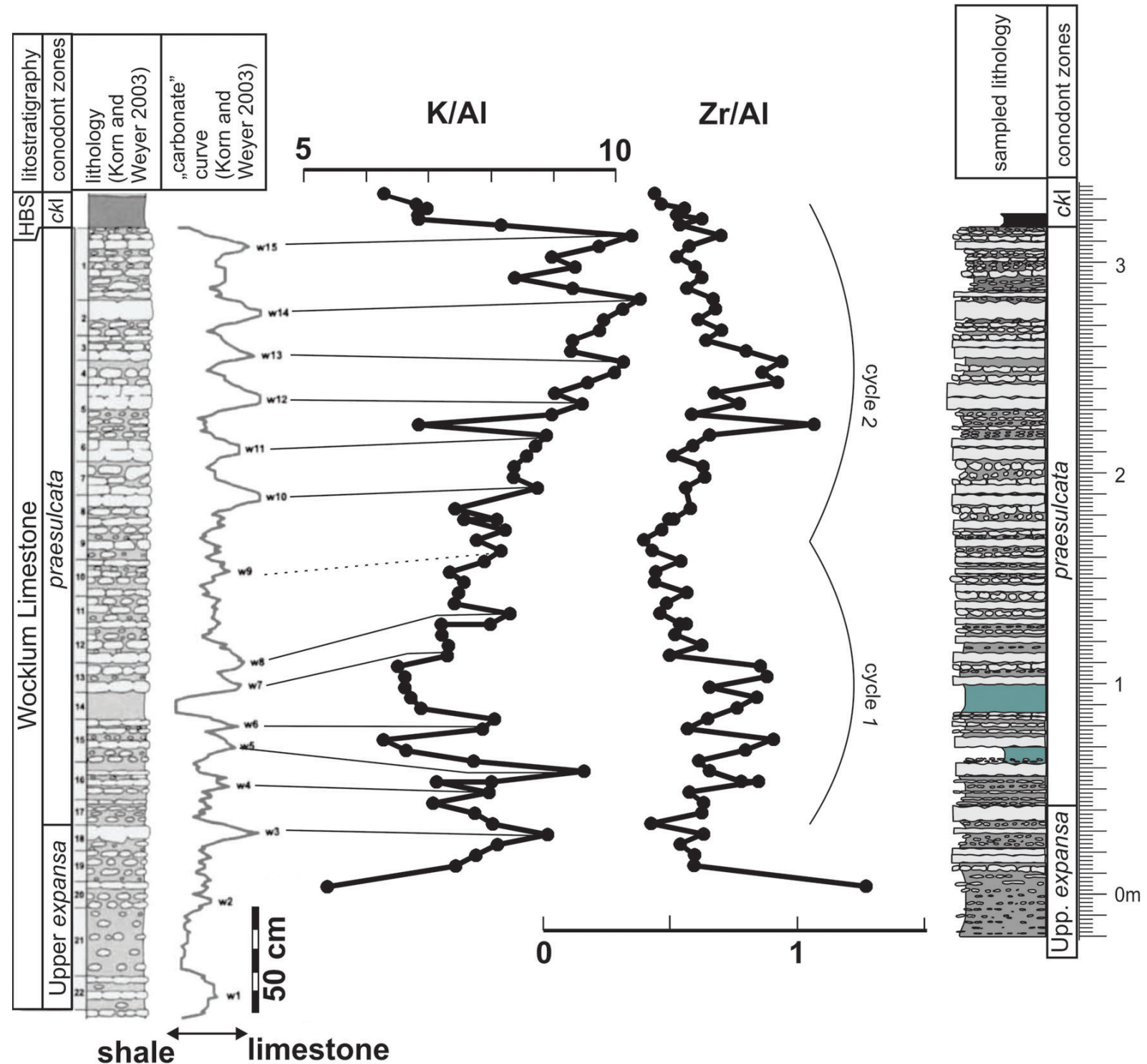

Figure 14. Correlation of the cyclic "carbonate" curve introduced by Korn \& Weyer (2003) with $\mathrm{K} / \mathrm{Al}$ and $\mathrm{Zr} / \mathrm{Al}$ curves. The "carbonate" curve was constructed by a bed-by-bed plotting of lithotypes (pure platy limestones, pure nodular limestones, limestone nodules in shales, shales with limestone nodules, shales with rare limestone nodules and pure shales or metabentonites) against the thickness.

lower order K/Al cycles varies from $<1 \mathrm{~m}$ (Drewer) to $\sim 1$ to $<2$ m (Oberrödinghausen and Oese) and correspond to alternation of bundles of layers.

The curves of a $\mathrm{Ni}+\mathrm{Cu}+\mathrm{Zn}+\mathrm{Pb}$ sum are uniform in the Wocklum Limestone at Oese and Drewer. Only at Oberrödinghausen high values were measured in intercalated shales of the praesulcata Zone $(0.12$ to $0.76 \mathrm{~m})$. $\mathrm{Ni}+\mathrm{Cu}+\mathrm{Zn}+\mathrm{Pb}$ display distinctive peaks in the Hangenberg Black Shale and Kahlenberg Formation in all sections studied (Figs 11-13).

The sulphur content is low and uniform in the lower part of the Wocklum Limestone in all studied sections and rises systematically towards the top of this member in the upper part of the praesulcata Zone at Oberrödinghausen
(Fig. 12) and Drewer (Fig. 13). In these two sections a drop in $\mathrm{S}$ content is related to the Hangenberg Black Shale deposition, which is followed by a sharp increase in the Hangenberg Sandstone at Drewer. An increasing trend of the $\mathrm{S}$ curve is characteristic of the Hangenberg Limestone at Drewer, whereas it is uniform or without distinctive trends in other sections.

Manganese curves show several horizons with higher values. Only an increase in Mn content at the top of the Wocklum Limestone was measured at all studied sections. A prominent increase in the lower part of the Wocklum Limestone was measured only at base of the Drewer section, and slightly higher values at Oberrödinghausen. Very low values are characteristic of the Hangenberg Black 
Shale and Sandstone at Drewer. Mn values are low in the lower part of Hangenberg Shale and grow towards its upper part at Oberrödinghausen and Oese. Mn values fluctuate between low to relatively high in the Hangenberg Sandstone. Two peaks take place at the base and top of the Hangenberg Limestone, respectively, at Oese. Systematic increase in Mn content was measured in the Hangenberg Limestone in Oberrödinghausen, whereas low values at Oese.

\section{Carbon isotope geochemistry}

The Hangenberg Event interval (from expansa to "hassi" Zones) was measured for inorganic carbon isotopes by Kaiser (2005) and Buggisch \& Joachimski (2006) at Oese and Drewer without distinctive correlative implications. Positive excursion in organic carbon isotopic composition was, however, documented in the Hangenberg Black Shales in the contiguous Hasselbachtal section (Kaiser et al. 2006). In this study we tried to examine the isotopic composition of the upper part of the Hangenberg Limestone from the "hassi" Zone up to the quadruplicata Zone. The aim was to find positive lower Tournaisian $\delta^{13} \mathrm{C}_{\text {carb }}$ anomaly, documented from the Namur-Dinant Basin, Belgium (Kumpan et al. 2014b) and Moravian Karst, Czech Republic (unpublished) and supplement previously published data.

Our isotopic dataset reveals a very high statistical correlation between $\delta^{18} \mathrm{O}$ and $\delta^{13} \mathrm{C}\left(\mathrm{R}^{2}=0.94\right)$ at Drewer (Fig. 15), which suggests that diagenetic alteration affected both oxygen and carbon isotopic composition (Allan \& Matthews 1982, Rossales et al. 2001, Veizer 2009). A decreasing trend towards the top of the Hangenberg Limestone is apparent (Figs 12, 13). Although the carbon and oxygen isotopes show very low linear correlation in the Oberrödinghausen section $\left(\mathrm{R}^{2}=0.02\right.$; Fig. 15), we consider this section to be diagenetically influenced because the measured values are very low and commonly negative. The decrease in $\delta^{13} \mathrm{C}_{\text {carb }}$ in the Oberrödinghausen section towards the top of the Hangenberg Limestone is systematic and distinctive (Fig. 12). High statistical correlation of $\delta^{18} \mathrm{O}$ and $\delta^{13} \mathrm{C}_{\text {carb }}$ (Drewer) and very low values (Drewer and Oberrödinghausen) are normally caused by bounding of light organic carbon during diagenetic recrystallization or weathering processes (Allan \& Matthews 1982). The decrease towards the top of the Hangenberg Limestone could be the result of such bounding of light organic carbon with a probable source in overlying organic-rich shales of the Kahlenberg Formation (Siegmund et al. 2002, Kerschke \& Schulz 2013).

\section{Regional correlation}

The correlative patterns of petrophysical and geochemical proxies were described in the previous sections (from

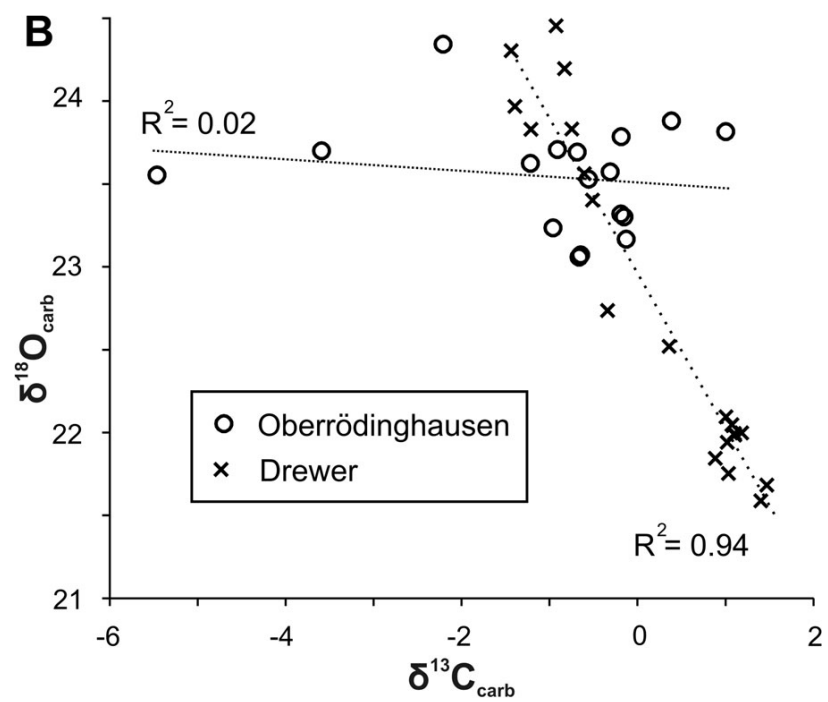

Figure 15. Bivariate plots of the $\delta^{13} \mathrm{C}_{\text {carb }}$ and $\delta^{18} \mathrm{O}_{\text {carb }}$.

"Gamma-ray spectrometry" to "Carbon isotope geochemistry"). These correlations can be regarded as robust because the majority of each proxy correlative tieline corresponds to the others (Fig. 16) and are all in agreement with the biostratigraphy. Together with the biostratigraphy and sedimentology it is, therefore, possible to designate 11 correlative ties, which can be traced between the studied sections.

\section{Discussion and interpretation}

\section{Depositional environment}

The prevailing lime muddy matrix with abundant heterotrophic pelagic faunal elements (represented mainly by cephalopods and thin-shelled bivalves) and the rare occurrence of sessile benthos reveal a relatively deep, subphotic (absence of algae), open shelf environment with soft muddy bottom substrate, well below the fair-weather wave base or even below storm wave base. Abundant mobile benthos (ostracodes, trilobites) and intensive burrowing indicate that the bottom was at least periodically sufficiently oxygenated during Wocklum and Hangenberg Limestone deposition. This is also supported by specialized benthos, such as some rhynchonellid brachiopods (Novaplatirostrum) and rare solitary rugose corals. Chaotic shell orientation, geopetal infill parallel to bedding as well as the common microfacies transitions (of MF1 to MF3) are probably a result of penecontemporaneous bioturbation of loose sediment, which obliterated primary sedimentary structures. During the following early-diagenetic phase (marine burial diagenesis; Melim et al. 1995), the carbonate mud was cemented, which is substantiated by the presence of burrows infilled by cements and non-compacted allochems. On the 
other hand, marl interlayers reveal features of compression and dissolution as was mentioned by Van Steenwinkel (1984). A relatively monotonous deposition in a deepwater environment is interpreted for the whole Wocklum and Hangenberg Limestone succession. The Hangenberg Black Shale and siliceous shales of the Kahlenberg Formation represent deposits of hypoxic bottom during times of clastic and carbonate starvation and increased palaeoproductivity. Only some opportunistic and very restricted benthos (the bivalve genus Guerichia) and nekton (the ammonoid species Postclymenia evoluta) flourished episodically in this environment. Episodes of oxic conditions during the HBSE were described from the Holly Cross Mountains, Poland (for detail reconstruction of deposition see Marynowski et al. 2012). Siltstones and sandstones of the Hangenberg Shale and Hangenberg Sandstone reveal sedimentary structures characteristic of turbidites, e.g., sharp bases with load structures, positive grading, and horizontal or cross stratiffication.

Sedimentological results from the investigated sections are in accordance with previous studies (e.g., Keupp \& Kompa 1984, Van Steenwinkel 1984, Siegmund et al. 2002, Hartenfels 2011) of the Upper Famennian and Lower Tournaisian sediments from the Rhenish Massif.

\section{Cyclicity}

As shown in sections "Lithology of the sections" and "Element geochemistry", the limestone-marl bed arrangement and some elemental proxy variations show a cyclic character in the studied sections. Thin lithological cycles (limestone-marl alternations) in the Wocklum Limestone (Upper expansa and praesulcata Zones) correlate well with $\mathrm{K} / \mathrm{Al}$ cycles of the higher order ( 20 to $\sim 30 \mathrm{~cm})$. Positive $\mathrm{K} / \mathrm{Al}$ peaks correspond to the peaks in the "carbonate" curve introduced by Korn \& Weyer (2003; Fig. 14) associated with pure nodular limestone beds. The documented lower-order K/Al cycles ( 1.0 to $\sim 2 \mathrm{~m}$ thickness; section "Element geochemistry") reflect alternation of bundles of layers. On the other hand, the $\mathrm{Zr} / \mathrm{Al}$ cycles are not in phase with the K/Al cycles and the limestone/marl alternations (Figs 11-14). The fact that individual element ratios reveal cycles of different order is not so surprising. A recent study of orbitally driven cyclicity in lacustrine sediments (Matys Grygar et al. 2014) has shown that, e.g., Al/Si and K/Al recorded eccentricity, obliquity and precession with different sensitivity. $\mathrm{K} / \mathrm{Al}$ is used as a proxy for clay mineral assemblages (see "Interpretative potential of petrophysical and geochemical proxies") and its cyclic fluctuations can be interpreted as changes in the weathering intensity and processes, which could be directly related to the original climate. On the other hand, the changes in $\mathrm{Zr} / \mathrm{Al}$ ratio of sediments are usually interpreted as a proxy for grain-size changes in the detrital fraction (see "Interpretative poten- tial of petrophysical and geochemical proxies"), which is transported to deep marine environment by wind (e.g. Hladil et al. 2010). Occurrence of the $\mathrm{Zr} / \mathrm{Al}$ peak in the metabentonite layer from the Wocklum Limestone at Oese points towards a volcanic source of the siliciclastics. On the other hand, we can assume from the relatively regular thickness of $\mathrm{Zr} / \mathrm{Al}$ cycles, combined with the fact that other $\mathrm{Zr} / \mathrm{Al}$ positive peaks are not tied to metabentonite beds, that volcanism was not the main controlling factor of $\mathrm{Zr} / \mathrm{Al}$ cyclicity.

The integrated approach of lithology and geochemistry hence supports the primary climatically driven character of cycles in the studied successions. Periodic cyclicity characteristic for the end-Famennian Wocklum Limestone is lost in the Hangenberg Events interval due to the change from hemipelagic to turbiditic sedimentation. $\mathrm{Zr} / \mathrm{Al}$ and $\mathrm{K} / \mathrm{Al}$ cyclicity is less obvious and correlatable in the Hangenberg Limestone, but limestone/marls cycles were described in detail by Korn \& Weyer (2003). Orbital forcing of the climatic changes and cyclicity in the Wocklum Limestone can be assumed, but the detailed interpretation of the particular steering forces is problematic. Two $\mathrm{Zr} / \mathrm{Al}$ cycles are documented from the praesulcata conodont Zone (Figs 11, 12, 13 and 16), whose duration has been estimated as $740 \mathrm{ka}$; Becker et al. 2012). Duration of one $\mathrm{Zr} / \mathrm{Al}$ cycle can therefore be very approximately estimated for $370 \mathrm{ka}$, which may correspond to the $405 \mathrm{ka}$ long-eccentricity period. The main problem with such an interpretation is that typical frequencies of Milankovitch cycles are not known for the Devonian (Hinnov \& Hilgen 2012) and that the extrapolation from the Cenozoic frequencies (e.g., Berger et al. 1989, House 1995) is arbitrary.

Because the cyclicity of the Wocklum Limestone seems to be a primary record of palaeoenvironmental oscillations, a downward extension of the high-resolution multiproxy stratigraphic analysis, through the Dasberg Black Shales and Dasberg Limestone to the Mid-Famennian Annulata Black Shales, would be important for the refinement of the Famennian chronostratigraphy, based on the orbital tuning analysis.

\section{Palaeoenvironmental and sequence stratigraphy interpretation}

The pre-Hangenberg Events regression (Bless et al. 1993, Becker 1996, Becker et al. 2002, Kaiser et al. 2011) is most distinctively recorded at Drewer (section Drewer-B), where the Drewer Sandstone, characterised by $\mathrm{Zr} / \mathrm{Al}$ positive peak, occurs few centimetres below the Wocklum Limestone top (uppermost part of praesulcata Zone). The Drewer Sandstone is missing at Oese and Oberrödinghausen, but a weaker peak in $\mathrm{Zr} / \mathrm{Al}$ at the top of the Wocklum 
Tomáš Kumpan et al. • Petrophysical and geochemical signature of the Hangenberg Events
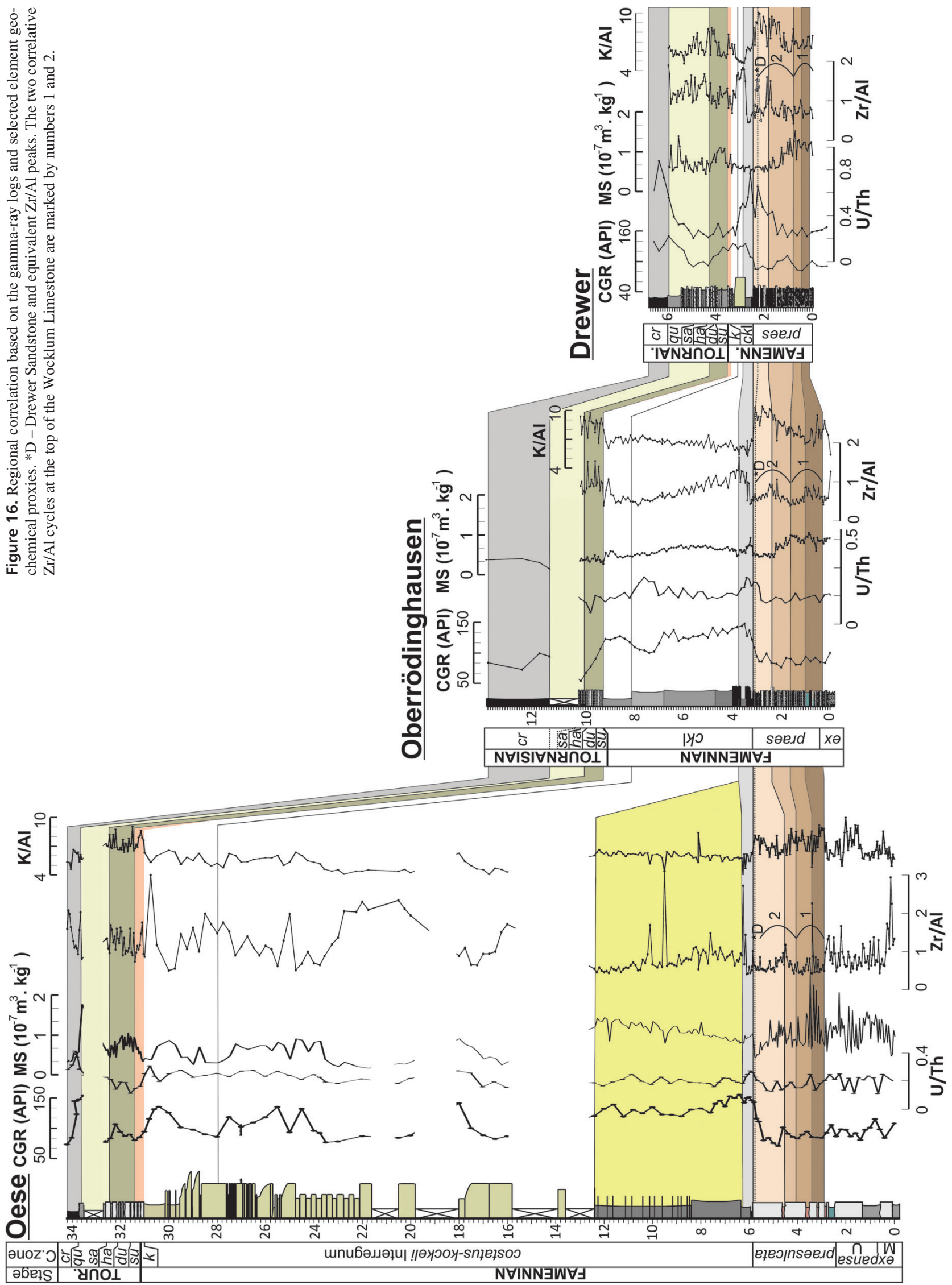
Limestone (marked by D in Fig. 16) can be correlated with this regressive pre-Events phase.

The second phase of the Hangenberg Events, HBSE, has previously been interpreted as the result of ocean eutrophication in times of enhanced deep-water upwelling, which resulted in hypoxia or anoxia, first-order mass extinction, and perturbation in the global carbon cycle (Caplan \& Bustin 1996, 1999; Kaiser et al. 2005, 2008). A brief warming accompanied by rapid sea-level rise at the base of the costatus-kockeli Interregnum was assumed to be the trigger of this event (Becker 1993a; Kaiser et al. 2006, 2008, 2011; De Vleeschouwer et al. 2013). Our results support previous interpretations and provide new evidence for decreasing oxygenation just prior to the Hangenberg Black Shale deposition in the top praesulcata Zone. Redox-sensitive U/Th values increase at the top of the Wocklum Limestone and reach a maximum in the Hangenberg Black Shale (base of the costatus-kockeli Interregnum) in all studied sections (Fig. 16), reflecting a somewhat gradual redox development towards hypoxic conditions, which were documented at Drewer (U/Th 0.77). The U/Th increase is moreover coeval with an increase in another redox-sensitive proxy, $\mathrm{S}$, which rises towards the top of the Wocklum Limestone with a maximum just under the Hangenberg Black Shale Event. An increase in $\mathrm{S}$ concentrations was related to the forming of sulphides in oxygen-depleted environments. Low $S$ values in the Hangenberg Black Shale at Oese and Oberrödinghausen are probably a consequence of secondary pyrite weathering, whose degradation is faster compared to organic matter weathering (Wildman et al. 2004, Marynowski et al. 2011). The onset of decreasing bottom oxygenation in the praesulcata Zone was obviously diachronous between the two studied regions. At Drewer it began within the Wocklum Limestone (lower part of praesulcata Zone; Figs 9 and 16), but at its top in the two other sections (upper part of praesulcata Zone; Figs 7, 8 and 16), as recorded by a change in U/Th and S curve trends. This could have been caused by the bathymetric differences between the deep intrabasinal swell (Drewer) and northern slope of the Remscheid-Altena High (Oese, Oberrödinghausen). Manganese peaks in the upper part of the Wocklum Limestone could be interpreted as a record of a fluctuating oxidation front $e$.g. during times of upwelling, when mobile Mn species dissolved and transported in reductive upwelled deep water to be precipitated and buried in carbonates just above the hypoxic-oxic interface (see "Interpretative potential of petrophysical and geochemical proxies"; Maynard 2005, Roy 2006). Very low Mn concentrations in the Hangenberg Black Shale and Sandstone from Drewer and the Hangenberg Shale at Oberrödinghausen support interpretation of deposition in a hypoxic to anoxic environment, when Mn is highly soluble (see "Interpretative potential of petrophysical and geochemical proxies"). Peak of the
$\mathrm{Cu}+\mathrm{Ni}+\mathrm{Zn}+\mathrm{Pb}$ proxy in the Hangenberg Black Shale can reflect enhanced palaeoproductivity and/or sulphide formation during the times of hypoxia or anoxia. Poor oxygenation at the top of the Wocklum Limestone and Hangenberg Black Shale was accompanied by a decrease in $\mathrm{Zr} / \mathrm{Al}$ ratio, perhaps as a consequence of gradual limitation of siliciclastic input into the basin because of trapping siliclastics in nearshore areas, typical during sea-level rises. However, the $\mathrm{Zr} / \mathrm{Al}$ minima in the Hangenberg Black Shale are by far not dramatic, having similar values as the preceding $\mathrm{Zr} / \mathrm{Al}$ cycles in the Wocklum Limestone. These older minima, however, are not associated with anoxia or enhanced bioproductivity indicators and "normal" limestone-marl rhythms were deposited without any marked facies change. This may suggest that the onset of the Hangenberg Black Shale deposition was probably related to the carbonate crisis, which was coeval with the peak in oxygen depletion and palaeoproductivity rates in the ocean, as assumed by Caplan \& Bustin (1996). As was mentioned previously, intensification of upwelling combined e.g., with volcanogenic oceanic acidification (Siegmund et al. 2002, Marynowski et al. 2012) could play a major role in the triggering of oceanic anoxia.

The overlying Hangenberg Shale reveals a rising trend in $\mathrm{Zr} / \mathrm{Al}$ ratio in the lower part, which probably corresponds to the increase in grain size due to the progradation of siliciclastic sediments over the extinct carbonate shelves. Van Steenwinkel (1984) and Kürschner et al. (1993) interpreted this phase as a sea-level still-stand. The third phase of the HE, the Hangenberg Sandstone Event, was related to a major global sea-level fall in the upper part of the costatus-kockeli Interregnum (e.g., Bless et al. 1993, Kalvoda et al. 1999, Isaacson et al. 2008, Kaiser et al. 2011, Streel et al. 2013). Glacigenic deposits documented in South and North America, South and possibly Central Africa were dated by palynomorphs as synchronous with the sea-level fall (Isaacson et al. 1999, 2008; Streel 2002; Caputo et al. 2008; Brezinski et al. 2008, 2010). Incised valleys infilled by siliciclastics were documented in Morocco (Kaiser et al. 2011) and the siliciclastic intervals overlying the Hangenberg Black Shale Event horizon in the Central Hunan (Hance et al. 1994), in Ohio and Kentucky (Coleman \& Clayton 1987) or Moravian Karst (Kumpan et al. 2014a), as well as in the studied sections from the Rhenish Massif (Bless et al. 1993, see Kaiser et al. 2011 and references therein). Inevitably for such a sea-level drop, gaps of variable stratigraphic extent are known from DCB in many places, e.g., Belgium (Hance $e t$ al. 1994, Kumpan et al. 2014b), Spain (García-Alcalde \& Menédez-Alvarez 1988), Colorado (Myrow et al. 2013) or Kentucky (Coleman \& Clayton 1987). The rapid increase in $\mathrm{Zr} / \mathrm{Al}$ ratio in the Hangenberg Sandstone at Drewer and Oese is consistent with the interpretation of $\mathrm{Zr} / \mathrm{Al}$ as 
a proxy for coarse-grained siliciclastics. A peak in $\mathrm{Zr} / \mathrm{Al}$ was also documented $55 \mathrm{~cm}$ above the base of the Hangenberg Shale at Oberrödinghausen, where abundant thin siltstones and rare fine-grained sandstones show a coarsening-upward trend. This $\mathrm{Zr} / \mathrm{Al}$ peak in fine-grained facies in this interval (Oberrödinghausen) can be correlated with the base of the Hangenberg Sandstone at Oese. The base of the HSE was previously interpreted as a sequence boundary in the Rhenish Massif (Van Steenwinkel 1984) as well as in the Namur-Dinant Basin (Belgium; Van Steenwinkel 1984), Tafilalt Basin (Morocco; Kaiser et al. 2011) and Western Canada Basin (Smith \& Bustin 2000). The basal surface of forced regression (Hunt \& Tucker 1992, Catuneanu et al. 2009), however, seems to be a more relevant type of sequence-stratigraphic surface to represent the base of HSE (Kumpan et al. 2014b). There are several reasons for this: (i) it is associated with a sudden switch from aggradation to progradation in deep-marine setting; (ii) it is associated with a sudden influx of terrigenous clastics; (iii) evidence from elsewhere suggest its coincidence with a glacieustatic sea-level fall. The upper portion of the Hangenberg Sandstone / Shale unit displays fining-upward patterns before the system returned to carbonate production in the kockeli Zone. Positive peaks in K/Al and less distinctive peaks in $\mathrm{Zr} / \mathrm{Al}$ just below the sulcata Zone base within the Stockum Limestone documented in Oese and Drewer are missing in Oberrödinghausen, which supports presence of the biostratigraphically detected stratigraphic gap (Bless et al. 1993) related to a minor sea-level fall (Kaiser et al. 2011). The Hangenberg Limestone is characterised by low U/Th values, which reflects return to normally oxygenated bottom after the HE, which is consistent with results of geochemical research of Siegmund et al. (2002). Peak of the $\mathrm{Cu}+\mathrm{Ni}+\mathrm{Zn}+\mathrm{Pb}$ proxy (in Oese; Fig. 11) accompanied by increase in U/Th in the Kahlenberg Formation (Fig. 16) again record the hypoxic event during enhanced palaeoproductivity, related to the sea-level rise (Becker 1993b, Zhuravlev 1998, Siegmund et al. 2002).

\section{Interregional correlations}

The selected petrophysical and geochemical proxies reveal similar patterns between the sections described herein and those previously studied in the Moravian Karst (Lesní lom, Mokrá and Křtiny quarries; Kumpan et al. 2014a) and Carnic Alps (Grüne Schneid; Kaiser et al. 2006, Kumpan et al. 2014a; Fig. 17). A decrease in terrigenous proxies (CGR, $\mathrm{Zr} / \mathrm{Al}$ and $\mathrm{Al}$ ) and increase in redox-sensitive U/Th and $\mathrm{Mn}$ take place just below the Hangenberg Black Shale Event in the high praesulcata Zone. U/Th reaches positive peaks and K/Al decreases in the Hangenberg Black Shale Event, coeval with $\delta^{13} \mathrm{C}$ positive excursion (Kaiser et al.

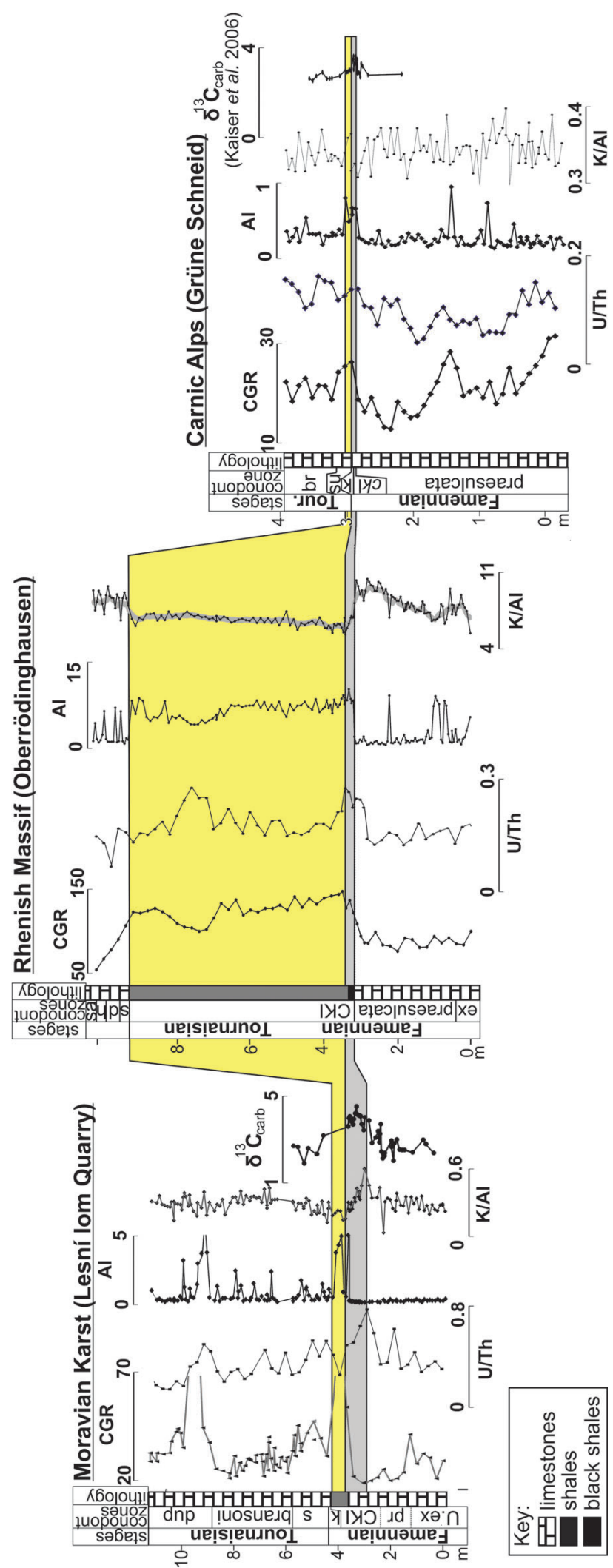

Figure 17. Interregional correlation of the Devonian-Carboniferous boundary interval from the northern Rhenish Massif with the Moravian Karst (Lesní lom Quarry) and Carnic Alps (Grüne Schneid), based on gamma-ray logs and selected elemental curves. 
2006, Kumpan et al. 2014a). Increase in detrital proxies (CGR, Zr/Al or Al) related to the Hangenberg Sandstone Event is well correlated among the above-mentioned sections.

MS curve of a relatively shallow-marine DCB succession from Pomerania, Poland (Matyja et al. 2015) reveals low values in the uppermost Famennian, which can be correlated with the curve from the Drewer section. On the other hand, the curves from Oese and Oberrödinghausen failed to show correlative pattern.

\section{Conclusions}

1. Our petrophysical and geochemical dataset confirms previous interpretations and additionally provides new insight into the palaeoenvironmental development prior and during the Hangenberg Events in the northern Rhenish Massif. U/Th and S vertical variations reveal a gradual decrease in bottom oxygenation despite brief shallowing (Drewer Sandstone Event) just before the Hangenberg Black Shale Event. The initiation of the oxygen depletion was regionally diachronous within the Wocklum Limestone because of bathymetric differences. Peaks in redox and palaeoproductivity proxies $(\mathrm{U} / \mathrm{Th}, \mathrm{Cu}+\mathrm{Ni}+\mathrm{Zn}+\mathrm{Pb})$ occur in the Hangenberg Black Shale and siliceous shales of the Kahlenberg Formation in all studied sections. Although sedimentation of the Hangenberg Black Shale took place during period of sea-level rise ( $\mathrm{Zr} / \mathrm{Al}$ decrease), very similar deepening steps are also recorded below the event without indices for hypoxy or anoxy. The Hangenberg Black Shale is therefore related to a carbonate crisis, which resulted from enhanced palaeoproductivity and anoxia.

2. Interregional correlation of the Hangenberg Events interval from the northern Rhenish Massif, the Moravian Karst and Carnic Alps was carried out, based on the elemental proxies. The most prominent correlative features are: a) increase in U/Th and decrease in terrigenous proxies (Al, $\mathrm{Zr} / \mathrm{Al})$ in the praesulcata Zone towards the Hangenberg Black Shale Event, b) low or decreasing K/Al or Zr/Al values in the Hangenberg Black Shale Event coeval with a positive $\delta^{13} \mathrm{C}$ peak and c) a positive $\mathrm{Zr} / \mathrm{Al}$ or $\mathrm{Al}$ peak in the Hangenberg Sandstone Event.

3. The primary origin of the limestone-marl cyclicity in the Famennian Wocklum Limestone has been supported by correlation with $\mathrm{K} / \mathrm{Al}$ ratio changes, which are independent of the carbonate rock diagenesis. K/Al curves display cyclicity of two orders. The higher-order cycles $(\sim 0.2$ to $0.3 \mathrm{~m}$ thick) clearly show individual limestone-marl cycles and may reflect weaker climatic oscillations. Lower-order $\mathrm{K} / \mathrm{Al}$ cyclicity ( $\sim 1$ to $2 \mathrm{~m}$ thick) follow the alternation of bundles of layers presumably controlled by climatic or eustatic oscillations of lower order. Duration of $\mathrm{Zr} / \mathrm{Al}$ cycles in the Wocklum Limestone was estimated as $370 \mathrm{ka}$, which is close to $405 \mathrm{ka}$ eccentricity.

\section{Acknowledgements}

This research has been financially supported by the Czech Science Foundation (grant number P210/11/1891). RTB and SH cooperated within the DFG research grant Be 1367/11-1. The manuscript benefited from reviews of James E. Day (Illinois State University), Xavier Devleeschouwer (Royal Belgian Institute of Natural Sciences), Hans-Georg Herbig (University of Cologne) and Leszek Marynowski (University of Silesia in Katowice).

\section{References}

AdAms, J.A.S. \& WeAver, C.E. 1958. Thorium-to-uranium ratios as indicators of sedimentary processes; example of concept of geochemical facies. American Association of Petroleum Geologists, Bulletin 42, 387-430.

Alberti, H., Groos-Uffenorde, H., Streel, M., Uffeneorde, H. \& WALliser, O.H. 1974. The stratigraphical significance of the Protognathodus fauna from Stockum (Devonian/Carboniferous boundary, Rhein. Schiefergebirge). Newsletters on Stratigraphy 3, 263-276.

Algeo, T.J., Scheckler, S.E. \& Maynard, B.J. 2001. Effects of the Middle to Late Devonian Spread of Vascular Land Plants on Weathering Regimes, Marine Biotas, and Global Climate, 213-236. In Gensel, P.G. \& Edwards, D. (eds) Plants invade the land. Evolutionary \& environmental perspectives. Columbia University Press, New York.

Allan, J.R. \& Matthews, R.K. 1982. Isotope signature associated with early meteoric diagenesis. Sedimentology 29, 797-897. DOI 10.1111/j.1365-3091.1982.tb00085.x

Almond, J., Marshall, J.E.A. \& Evans, F. 2002. Latest Devonian and earliest Carboniferous glacial events in South Africa. $16^{\text {th }}$ International Sedimentological Congress, Abstracts, 11-12.

Aubry, M.P., Ouda, K., Dupuis, C., Berggren, W.A., van Couvering, J.A. AND MEMBERs OF THE Working Group On the PALEOCEne/EOCEnE BOUndary 2007. The global standard stratotype section and point (GSSP) for the base of the Eocene Series in the Dababiya section (Egypt). Episodes 30, 271-286.

Bábek, O., Kalvoda, J., Aretz, M., Cossey, P.J., Devuyst, F.X., Herbig, H.G. \& Sevastopulo, G. 2010. The correlation potantial of magnetic susceptibility and outcrop gamma-ray logs at Tournaisian-Viséan boundary sections in Western Europe. Geologica Belgica 13, 291-308.

Bábek, O., Kalvoda, J., Cossey, P., Šimíček, D., Devuyst, F.X. $\&$ HARgreAvES, S. 2013. Facies and petrophysical signature of the Tournaisian/Viséan (Lower Carboniferous) sea-level cycle in carbonate ramp to basinal settings of the Wales-Brabant massif, British Isles. Sedimentary Geology 284-285, 197-213. DOI 10.1016/j.sedgeo.2012.12.008

BECKER, R.T. 1988. Ammonoids from the Devonian-Carboniferous Boundary in the Hasselbach Valley (Northern Rhenish 
Slate Mountains). Courier Forschungsinstitut Senckenberg 100, 193-213.

BECKER, R.T. 1992. Zur Kenntnis von Hemberg-Stufe und Annulata-Schiefer im Nordsauerland (Oberdevon, Rheinisches Schiefergebirge, GK 4611 Hohenlimburg). Berliner geowissenschaftliche Abhandlungen E3, 3-41.

BECKER, R.T. 1993a. Analysis of ammonoid palaeobiogeography in relation to the global Hangenberg (terminal Devonian) and Lower Alum Shale (Middle Tournaisian) events. Annales de la Société Géologique de Belgique 115(2), 459-473.

BECKER, R.T. 1993b. Anoxia, eustatic changes, and Upper Devonian to Lowermost Carboniferous global ammonoid diversity. The Systematics Association, Special Volume 47, 115-164.

BECKER, R.T. 1996. New faunal records and holostratigraphic correlation of the Hasselbachtal D/C-boundary auxiliary stratotype (Germany). Annales de la Société Géologique de Belgique 117, 19-45.

BECKER, R.T. 2000. Taxonomy, evolutionary history and distribution of the middle to late Famennian Wocklumeriina (Ammonoidea, Clymeniida). Mitteilungen aus dem Museum für Naturkunde Berlin, geowissenschaftliche Reihe 3, 27-75.

Becker, R.T., Ashouri, A.R. \& Yazdi, M. 2004. The Upper Devonian Annulata Event in the Shotori Range (eastern Iran). Neues Jahrbuch für Geologie und Paläontologie, Abhandlungen 231(1), 119-143.

Becker, R.T., Bless, M.J.M., Brauckmann, C., Friman, L., Higgs, K., Keupp, H., Korn, D., Langer, W., Paproth, E., Racheboeuf, P., Stoppel, D., Streel, M. \& Zakowa, H. 1984. Hasselbachtal, the section best displaying the Devonian-Carboniferous boundary beds in the Rhenish Massif (Rheinisches Schiefergebirge). Courier Forschungsinstitut Senckenberg 67, 23-28.

Becker, R.T., Gradstein, F.M. \& Hammer, O. 2012. The Devonian Period, 559-601. In Gradstein, F.M., OGG, J.G., SchmitZ, M.D. \& OGG, G.M. (eds) The geologic time scale 2012, volume 2. Elsevier, Oxford, Amsterdam, Waltham.

Becker, R.T., Hartenfels, S., Aboussalam, Z.S., Tragelehn, H., Brice, D. \& El Hassani, A. 2013. The Devonian-Carboniferous boundary at Lalla Mimouna (northern Maider) - a progress report. Document de l'Institut Scientifique, Rabat 27, 109-120.

Becker, R.T., House, M.R, Bockwinkel, J., Ebbighausen, V. \& Aboussalam, Z.S. 2002. Famennian ammonoid zones of the eastern Anti-Atlas (southern Morocco). Münstersche Forschungen zur Geologie und Paläontologie 93, 159-205.

Becker, R.T., Korn, D., Paproth, E. \& Streel, M. 1993. Beds near the Devonian-Carboniferous boundary in the Rhenish Massif, Germany. IUGS Commission on Stratigraphy, Subcommission on Carboniferous Stratigraphy (SCCS), Guidebook. 86 pp. Services associés de paléontologie de l'ULg.

BECKER, R.T. \& PAPROTH, E. 1993. Auxiliary stratotype sections for the Global Stratotype Section and Point (GSSP) for the Devonian-Carboniferous boundary: Hasselbachtal. Annales de la Société Géologique de Belgique 115, 703-706.

Berger, A., Loutre, M.F. \& Dehant, V. 1989. Pre-Quarternary Milankovitch frequencies. Nature 323, 133. DOI 10.1038/342133b0

Bless, M.J.M., Becker, R.T., Higgs, K., Paproth, E. \& Streel, M. 1993. Eustatic cycles around the Devonian-Carboniferous boundary and the sedimentary and fossil record in Sauerland (Federal Republic of Germany). Annales de la Société Géologique de Belgique 115(2), 689-702.

Bout-Roumazeilles, V., Combourieu-Nebout, N., Desprat, S., Siani, G., Turon, J.L. \& Essallami, L. 2013. Tracking atmospheric and riverine terrigenous supplies variability during the last glacial and the Holocene in central Mediterranean. Climate of the Past 9, 1065-1087. DOI 10.5194/cp-9-1065-2013

Brezinski, D.K., Cecil, C.B. \& Skema, V.W. 2010. Late Devonian glacigenic and associated facies from the central Appalachian Basin, eastern United States. GSA Bulletin 122(1/2), 265-281. DOI 10.1130/B26556.1

Brezinski, D.K., Cecil, B., Skema, V.W. \& Stamm, R. 2008. Late Devonian glacial deposits from the eastern United States signal an end of the mid-Paleozoic warm period. Palaeogeography, Palaeoclimatology, Palaeoecology 268, 143-151. DOI 10.1016/j.palaeo.2008.03.042

BugGisch, W. \& JoAChimski, M.M. 2006. Carbon isotope stratigraphy of the Devonian of central and southern Europe. Palaeogeography, Palaeoclimatology, Palaeoecology 240, 66-88. DOI 10.1016/j.palaeo.2006.03.046

Calvert, S.E. \& Pedersen, T.F. 1993. Geochemistry of recent oxic and anoxic marine sediments - implications for the geological record. Marine Geology 113, 67-88.

DOI 10.1016/0025-3227(93)90150-T

Caplan, M.L. \& Bustin, R.M. 1999. Devonian-Carboniferous Hangenberg mass extinction event, widespread organic-rich mudrock and anoxia: causes and consequences. Palaeogeography, Palaeoclimatology, Palaeoecology 148, 187-207. DOI 10.1016/S0031-0182(98)00218-1

CAPLAn, M.L. \& Bustin, M.R. 2001. Palaeoenvironmental and palaeoceanographic controls on black, laminated mudrock deposition: example from Devonian-Carboniferous strata, Alberta, Canada. Sedimentary Geology 145, 45-72. DOI 10.1016/S0037-0738(01)00116-6

Caplan, M.L. \& Bustin, M.R. 2008. Palaeoceanographic controls on geochemical characteristics of organic-rich Exshaw mudrocks: role of enhanced primary production. Organic Geochemistry 30, 161-188.

DOI 10.1016/S0146-6380(98)00202-2

Caplan, M.L., Bustin, R.M. \& Grimm, K.A. 1996. Demise of a Devonian-Carboniferous carbonate ramp by eutrophication. Geology 24, 715-718.

DOI 10.1130/0091-7613(1996)024<0715:DOADCC >2.3.CO;2

Caputo, M.V., Melo, J.H.M., Streel, M. \& Isbell, J.L. 2008. Late Devonian and Early Carboniferous glacial records of South America. Geological Society of America, Special Papers 441, 161-173. DOI 10.1130/2008.2441(11)

Catuneanu, O., Abreu, V., Bhattacharya, J.P., Blum, M.D., Dalrymple, R.W., Eriksson, P.G., Fielding, C.R., Fisher, W.L., Galloway, W.E., Gibling, M.R., Giles, K.A., Holbrook, J.M., Jordan, R., Kendall, C.G.S.C., Macurda, B., Martinsen, O.J., Miall, A.D., Neal, J.E., Nummedal, D., Pomar, L., Posamentier, H.W., Pratt, B.R., SARg, J.F., Shanley, K.W., Steel, R.J., Strasser, A., Tucker, M.E. \& Winker, C. 2009. Towards the standardization of sequence stratigraphy. Earth-Science Reviews 92, 1-33.

DOI 10.1016/j.earscirev.2008.10.003

Chen, D., Wang, J., Racki, G., Li, H., Wang, C., Ma, X. \& 
Whalen, M.T. 2013. Large sulphur isotopic perturbations and oceanic changes during the Frasnian-Famennian transition of the Late Devonian. Journal of the Geological Society 170, 465-476. DOI 10.1144/jgs2012-037

Clausen, C.-D., Leuteritz, K., Ziegler, W. \& Korn, D. 1989. Ausgewählte Profile an der Devon/Karbon-Grenze im Sauerland (Rheinisches Schiefergebirge). Fortschritte in der Geologie von Rheinland und Westfalen 35, 161-226.

Coleman, U. \& Clayton, G. 1987. Palynostratigraphy and palynofacies of the uppermost Devonian and Lower Mississippian of eastern Kentucky (U.S.A.), and correlation with western Europe. Courier Forschungsinstitut Senckenberg 98, 75-93.

Corradini, C., Kaiser, S.I., Perri, M.C. \& Spalleta, C. 2011. Protognathodus (conodonta) and its potential as a tool for defining the Devonian/Carboniferous boundary. Rivista Italiana di Paleontologia e Stratigrafia 117, 15-28.

Crick, R.E., Ellwood, B.B., Hladil, J., El Hassani, A., Feist, R. \& HLADIL, J. 1997. Magnetosusceptibility event and cyclostratigraphy (MSEC) of the Eifelian-Givetian GSSP and associated boundary sequences in North Africa and Europe. Episodes 20, 167-175.

Da Silva, A.C., Yans, J. \& Boulvain, F. 2010. Early-Middle Frasnian (early Late Devonian) sedimentology and magnetic susceptibility of the Ardennes area (Belgium): identification of severe and rapid sea-level fluctuations. Geologica Belgica 13, 319-332.

DEAN, W.E. 2007. Sediment geochemical records of productivity and oxygen depletion along the margin of western North America during the past 60,000 years: teleconnections with Greenland Ice and the Cariaco Basin. Quaternary Science Reviews 26, 98-114.

DOI 10.1016/j.quascirev.2006.08.006

De Vleeschouwer, D., RAKociński, M., Racki, G., Bond, D.P.G., Sobień, K. \& ClaEys, P. 2013. The astronomical rhythm of Late-Devonian climate change (Kowala section, Holy Cross Mountains, Poland). Earth and Planetary Science Letters 365, 25-37. DOI 10.1016/j.epsl.2013.01.016

Doveton, J.H. 1991. Lithofacies and geochemical-facies profiles from nuclear wireline logs. Kansas Geological Survey Bulletin 233, 101-110.

Doveton, J.H. 1994. Geologic Log Interpretation: Reading the Rocks from Wireline Logs. 169 pp. SEPM Short Course Notes 29, Tulsa.

Doveton, J.H. \& Merriam, D.F. 2004. Borehole petrophysical chemostratigraphy of Pennsylvanian black shales in the Kansas subsurface. Chemical Geology 206, 249-258. DOI 10.1016/j.chemgeo.2003.12.027

Eckelmann, K., Nesbor, H.-D., Königshof, P., Linnemann, U., Hofmann, M., Lange, J.-M. \& Sagawe, A. 2014. Plate interactions of Laurussia and Gondwana during the formation of Pangea - Constraints from U-Pb LA-SF-ICP-MS detrital zircon ages of Devonian and Early Carboniferous siliciclastics of the Rhenohercynian zone, Central European Variscides. Gondwana Research 25(4), 1484-1500.

DOI 10.1016/j.gr.2013.05.018

EhrenBerG, S.N. \& SvanA, T.A. 2001. Use of spectral gammaray signature to interpret stratigraphic surfaces in carbonate strata; an example from the Finnmark carbonate platform
(Carboniferous-Permian), Barents Sea. American Association of Petroleum Geologists, Bulletin 85, 295-308.

EicкноғF, G. 1973. Das hohe Oberdevon und tiefe Unterkarbon im Bahneinschnitt Oberrödinghausen bei Menden (Rheinisches Schiefergebirge). Compte Rendu, Septième Congrés International de Stratigraphie et Géologie du Carbonifère, Krefeld 23.-28. August 1971, vol. II, 417-434.

Ellwood, B.B., Crick, R.E. \& El Hassani, A. 1999. Magnetosusceptibility event and cyclostratigraphy (MSEC) method used in geological correlation of Devonian rocks from Anti-Atlas Morocco. The American Association of Petroleum Geologists, Bulletin 83, 1119-1134.

FIELDING, C.R., FRANK, T.D. \& IsBell, J.L. (eds) 2008. Resolving the Late Palaeozoic ice age in time and space. Geological Society of America, Special Paper 441, 97-114.

DOI 10.1130/2008.2441(07)

Fralick, P.W. \& KronBerg, B.I. 1997. Geochemical discrimination of clastic sedimentary rock sources. Sedimentary Geology 113, 111-124. DOI 10.1016/S0037-0738(97)00049-3

FrANKE, W. 1999. Tectonic and plate tectonic units at the North Gondwana margin: Evidence from the central European Variscides. Abhandlungen der Geologischen Bundesanstalt 54, 7-13.

García-Alcalde, J.L. \& Mendéz Alvarez, J.R. 1988. The Devonian-Carboniferous boundary in the Asturo-leonese Domain (Cantabrian Mountains, NW Spain). Courier Forschungsinstitut Senckenberg 100, 21-37.

Gereke, M. \& Schindler, E. 2012. "Time-Specific Facies" and biological crises - The Kellwasser Event interval near the Frasnian/Famennian boundary (Late Devonian). Palaeogeography, Palaeoclimatology, Palaeoecology 367-368, 19-29. DOI 10.1016/j.palaeo.2011.11.024

Griffin, J., Windom, H. \& GoldBerG, E. 1968. The distribution of clay minerals in the World Ocean. Deep Sea Research and Oceanographic Abstract 15(4), 433-459. DOI 10.1016/0011-7471(68)90051-X

Hance, L., Muchez, P., Coen, M., Fang, X.-S., Groessens, E., Hou, H., Poty, E., Steemans, P., Streel, M., Tan, Z., Tourneur, F., van Steenwinkel, M. \& Xu, S.C. 1994. Biostratigraphy and sequence stratigraphy at the Devonian-Carboniferous transition in Southern China (Hunan Province). Comparison with southern Belgium. Annales de la Société Géologique de Belgique 116, 359-378.

Hance, L. \& Poty, E. 2006. Hastarian. Geologica Belgica 9, 111-116.

Hartenfels, S. 2011. Die globalen Annulata-Events und die Dasberg-Krise (Famennium, Oberdevon) in Europa und NordAfrika - hochauflösende Conodonten-Stratigraphie, KarbonatMikrofazies, Paläoökologie und Paläodiversität. Münstersche Forschungen zur Geologie und Paläontologie 105, 17-527.

Hartenfels, S. \& BecKer, R.T. 2009. Timing of the global Dasberg Crisis - implications for Famennian eustasy and chronostratigraphy. Palaeontographica Americana 63, 69-95.

Higgs, K.T. \& Streel, M. 1994. Palynological age for the lower part of the Hangenberg Shales in Sauerland, Germany. Annales de la Société géologique de Belgique 116, 243-247.

Hinnov, L.A. \& Hilgen, F.J. 2012. Cyclostratigraphy and 
Astrochronology, 63-84. In Gradstein, F.M., OGG, J.G., Schmitz, M.D. \& OGG, G.M. (eds) The geologic time scale 2012, volume 1. Elsevier, Oxford, Amsterdam, Waltham.

Hladil, J., Čejchan, P., Bábek, O., Koptíková, L., Navrátil, T. \& KubínovÁ, P. 2010. Dust - a geology-orientated attempt to reappraise the natural components, amounts, inputs to sediment, and importance for correlation purposes. Geologica Belgica 13(4), 367-384.

Hladil, J., Geršl, M., Strnad, L., Frána, J., Langrová, A. \& SPIŠIAK, J. 2006. Stratigraphic variation of complex impurities in platform limestones and possible significance of atmospheric dust: a study with emphasis on gamma-ray spectrometry and magnetic susceptibility outcrop logging (Eifelian-Frasnian, Moravia, Czech Republic). International Journal of Earth Sciences 95, 703-723.

DOI 10.1007/s00531-005-0052-8

House, M.R. 1985. Correlation of mid-Paleozoic ammonoid evolutionary events with global sedimentary perturbations. $\mathrm{Na}$ ture $313,17-22$. DOI 10.1038/313017a0

House, M.R. 1993. Earliest Carboniferous goniatite recovery after the Hangenberg Event. Annales de la Société Géologique de Belgique 115(2), 559-579.

House, M.R. 1995. Orbital forcing timescales: an introduction, 1-18. In House, M.R. \& Gale, A.S. (eds) Orbital Forcing Timescales and Cyclostratigraphy. Geological Society Special Publication 85.

House, M.R. 2002. Strength, timing, setting and cause of midPalaeozoic extinctions. Palaeogeography, Palaeoclimatology, Palaeoecology 181, 5-25. DOI 10.1016/S0031-0182(01)00471-0

Hunt, D. \& Tucker, M.E. 1993. Sequence stratigraphy of carbonate shelves with an example from the mid-Cretaceous (Urgonian) of Southeast France, 307-341. In Posamentier, H.W., Summerhayes, C.P., Haq, B.U. \& Allen, G.P. (eds) Sequence Stratigraphy and Facies Associations. Special Publication, vol. 18. International Association of Sedimentologists.

Isaacson, P., Díaz-Martínez, E., Grader, G.W., Kalvoda, J., BÁbeK, O. \& Devuyst, F.X. 2008. Late Devonian-earliest Mississippian glaciation in Gondwanaland and its biogeographic consequences. Palaeogeography, Palaeoclimatology, Palaeoecology 268, 126-142.

DOI 10.1016/j.palaeo.2008.03.047

Isaacson, P.E., Hladil, J., Shen, J.W., Kalvoda, J. \& Grader, G. 1999. Late Devonian (Famennian) glaciation in South America and marine offlap on other continents. Abhandlungen der Geologischen Bundesanstalt 54, 239-257.

Jones, B. \& MANNIng, D.A.C. 1994. Comparison of geochemical indices used for the interpretation of paleoredox conditions in ancient mudstone. Chemical Geology 111, 111-129. DOI 10.1016/0009-2541(94)90085-X

KAISER, S.I. 2005. Mass extinctions, climatic and oceanographic changes at the Devonian-Carboniferous boundary. $156 \mathrm{pp}$. Ph.D. thesis, Ruhr University, Bochum, Germany.

KaISER, S.I. 2009. The Devonian/Carboniferous stratotype section La Serre (Montagne Noire) revisited. Newsletters on Stratigraphy 43, 195-205.

DOI 10.1127/0078-0421/2009/0043-0195

Kaiser, S.I., Becker, R.T., Spaletta, C. \& Steuber, T. 2009.
High-resolution conodont stratigraphy, biofacies, and extinctions around the Hangenberg Event in pelagic successions from Austria, Italy, and France. Palaeontographica Americana 63, 99-143.

Kaiser, S.I., Becker, R.T., Steuber, T. \& Aboussalam, Z.S. 2011. Climate-controlled mass extinctions, facies, and sea-level changes around the Devonian-Carboniferous boundary in the eastern Anti-Atlas (SE Morocco). Palaeogeography, Palaeoclimatology, Palaeoecology 310, 340-364. DOI 10.1016/j.palaeo.2011.07.026

KAISER, S.I. \& CoRradini, C. 2011. The early siphonodellids (Conodonta, Late Devonian-Early Carboniferous): overview and taxonomic state. Neues Jahrbuch für Geologie und Paläontologie, Abhandlungen 261, 19-35.

DOI 10.1127/0077-7749/2011/0144

Kaiser, S.I., Steuber, T. \& Becker, R.T. 2008. Environmental change during the Late Famennian and Early Tournaisian (Late Devonian-Early Carboniferous): implications from stable isotopes and conodont biofacies in southern Europe. Geological Journal 43, 241-260. DOI 10.1002/gj.1111

Kaiser, S.I., Steuber, T., Becker, R.T. \& JoAchimski, M.M. 2006. Geochemical evidence for major environmental change at the Devonian-Carboniferous boundary in the Carnic Alps and the Rhenish Massif. Palaeogeography, Palaeoclimatology, Palaeoecology 240, 146-160.

DOI 10.1016/j.palaeo.2006.03.048

KALVODA, J. 1989: Tournaisian events in Moravia and their significance. Courier Forschungsinstitut Senckenberg 117, 353-358.

KALVODA, J. 1986. Upper Frasnian-Lower Tournaisian events and evolution of calcareous foraminifera, close links to climatic changes, 225-236. In Walliser, O.H. (ed.) Global Bioevents: a critical approach. Lecture Notes in Earth Sciences 8. Springer Verlag, Berlin.

KalvodA, J. 2002. Late Devonian - Early Carboniferous foraminiferal fauna: zonation, evolutionary events, paleobiogegraphy and tectonic implications. Folia Facultatis scientiarium naturalium Universitatis Masarykianae Brunensis, Geologia 39, 1-213.

Kalvoda, J., Kumpan, T. \& BÁBeK, O. 2015. Upper Famennian and Lower Tournaisian sections of the Moravian Karst (Moravo-Silesian Zone, Czech Republic): a proposed key area for correlation of the conodont and foraminiferal zonations. Geological Journal 50, 17-38. DOI 10.1002/gj.2523

KeLLER, G. 2011. Defining the Cretaceous-Tertiary boundray: a practical guide and return to first principles. SEPM Special Publication 100, 23-43.

Kerschre, D. \& Schulz, H.M. 2013. The shale gas potential of Tournaisian, Visean, and Namurian black shales in North Germany: baseline parameters in a geological context. Environmental Earth Sciences 70, 3817-3837.

DOI 10.1007/s12665-013-2745-9

Keupp, H. \& Kompa, R. 1984. Mikrofazielle und sedimentologische Untersuchungen an Devon/Karbon Profilen am Nordrand des rechtsrheinischen Schiefergebirges. Courier Forschungsinstitut Senckenberg 67, 139-142.

KoRn, D. 1984. Die Goniatiten der Stockumer ImitocerasKalklinsen. Courier Forschungsinstitut Senckenberg 67, 71-89. 
Korn, D. 1988. On the stratigraphical occurrence of Cymaclymenia evoluta (H. Schmidt 1924) at the type locality. Courier Forschungsinstitut Senckenberg 100, 215-216.

Korn, D. 1991. Threedimensionally preserved clymeniids from the Hangenberg Black Shale of Drewer (Cephalopoda, Ammonoidea; Devonian/Carboniferous boundary, Rhenish Massif). Neues Jahrbuch für Geologie und Paläontologie, Monatshefte 119(9), 553-563.

Korn, D. 1993. The ammonoid faunal change near the Devonian-Carboniferous boundary. Annales de la Société Géologique de Belgique 115(2), 581-593.

Korn, D. 2010. Lithostratigraphy and biostratigraphy of the Kulm succession in the Rhenish Mountains. Zeitschrift der deutschen Gesellschaft für Geowissenschaften 161(4), 431-453. DOI 10.1127/1860-1804/2010/0161-0431

KonN, D. 2015. Kahlenberg Formation. In LithoLex [Online-Datenbank]. Record No. 6004003. BGR, Hannover. Last updated 08.04.2015. [cited 11.06.2015]. Available from http://www.bgr.bund.de/litholex.

Korn, D., Clausen, C.-D. \& Luppold, F.W. 1994. Die Devon/Karbon-Grenze im Rheinischen Schiefergebirge. Geologie und Paläontologie in Westfalen 29, 1-221.

Korn, D., PIECHA, M. \& Wrede, V. 2010. Hasselbachtal section an auxiliary stratotype for the Devonian-Carboniferous Boundary. Schriftenreihe der Deutschen Gesellschaft für Geowissenschaften 66, 66-67.

Korn, D. \& WeYER, D. 2003. High resolution stratigraphy of the Devonian-Carboniferous transitional beds in the Rhenish Mountains. Mitteilungen aus dem Museum für Naturkunde in Berlin, Geowissenschaftliche Reihe 6, 79-124.

Kumpan, T., Bábek, O., Kalvoda, J., Frýda, J. \& Matys GrYGaR, T. 2014a. A high-resolution, multiproxy stratigraphic analysis of the Devonian-Carboniferous boundary sections in the Moravian Karst (Czech Republic) and a correlation with the Carnic Alps (Austria). Geological Magazine 151, 201-215. DOI 10.1017/S0016756812001057

Kumpan, T., Bábek, O., Kalvoda, J., Matys Grygar, T. \& FRÝDA, J. 2014b. Sea-level and environmental changes around the Devonian-Carboniferous boundary in the Namur-Dinant Basin (S Belgium, NE France): a multi-proxy stratigraphic analysis of carbonate ramp archives and its use in regional and interregional correlations. Sedimentary Geology 311, 43-59. DOI 10.1016/j.sedgeo.2014.06.007

Kürschner, W., Becker, R.T., Buhl, D. \& Veizer, J. 1993. Strontium isotopes in conodonts: Devonian-Carboniferous transition, the northern Rheinisches Schiefergebirge, Germany. Annales de la Société Géologique de Belgique 115(2), 595-621.

Lüning, S., Wendt, J., Belka, Z. \& Kaufmann, B. 2004. Temporal-spatial reconstruction of the early Frasnian (Late Devonian) anoxia in NW Africa; new field data from the Ahnet Basin (Algeria). Sedimentary Geology 163, 237-264.

DOI 10.1016/S0037-0738(03)00210-0

Luppold, F.W., Clausen, C.-D., Korn, D. \& Stoppel, D. 1994. Devon/Karbon-Grenzprofile im Bereich von RemscheidAltenaer Sattel, Warsteiner Sattel, Briloner Sattel und Attendorn-Elsper Doppelmulde (Rheinisches Schiefergebirge). Geologie und Paläontologie in Westfalen 29, 7-69.

Luppold, F.W., Hahn, G. \& Korn, D. 1984. Trilobiten-,
Ammonoideen- und Conodonten-Stratigraphie des Devon/Karbon-Grenzprofiles auf dem Müssenberg (Rheinisches Schiefergebirges). Courier Forschungsinstitut Senckenberg 67, 91-121.

Marynowski, L. \& FilipiaK, P. 2007. Water column euxinia and wildfire evidence during deposition of the Upper Famennian Hangenberg event horizon from the Holy Cross Mountains (central Poland). Geological Magazine 144, 569-595. DOI 10.1017/S0016756807003317

Marynowski, L., Filipiak, P. \& Zatoń, M. 2010. Geochemical and palynological study of the Upper Famennian Dasberg event horizon from the Holy Cross Mountains (central Poland). Geological Magazine 147, 527-550.

DOI 10.1017/S0016756809990835

Marynowski, L., Kurkiewicz, S., Rakocinski, M. \& Simoneit, B.R.T. 2011. Effects of weathering on organic matter: I. Changes in molecular composition of extractable organic compounds caused by paleoweathering of a Lower Carboniferous (Tournaisian) marine black shale. Chemical Geology 285, 144-156. DOI 10.1016/j.chemgeo.2011.04.001

Marynowski, L., Zatoń, M., Rakociński, M., Filipiak, P., Kurkiewicz, S. \& Pearce, T.J. 2012. Deciphering the upper Famennian Hangenberg Black Shale depositional environments based on multi-proxy record. Palaeogeography, Palaeoclimatology, Palaeoecology 346-347, 66-86.

DOI 10.1016/j.palaeo.2012.05.020

Matyja, H., Sobień, K., Marynowski, L., Stempień-Salek, M. \& MalkowsKi, K. 2014. The expression of the Hangenberg Event (latest Devonian) in a relatively shallow-marine succession (Pomeranian Basin, Poland): the results of a multi-proxy investigation. Geological Magazine 152, 400-428.

DOI 10.1017/S001675681400034X

Matys Grygar, T., Mach, K., Schnabl, P., Pruner, P., Laurin, J. \& Martinez, M. 2014. A lacustrine record of the early stage of the Miocene Climatic Optimum in Central Europe from the Most Basin, Ohře (Eger) Graben, Czech Republic. Geological Magazine 151(6), 1013-1033.

DOI $10.1017 /$ S0016756813001052

Maynard, J.B. 2005. Manganiferous sediments, rocks, and ores, 289-308. In Mackenzie, F.T. (ed.) Sediments, Diagenesis, and Sedimentary Rocks, Treatise on Geochemistry 7. Elsevier, Amsterdam.

Melim, L.A., Swart, P.K. \& Maliva, R.G. 1995. Meteoric-like fabrics forming in marine waters: implications for the use of petrography to identify diagenetic environments. Geology 23, 755-758.

DOI 10.1130/0091-7613(1995)023<0755:MLFFIM>2.3.CO;2

Myrow, P.M., Hanson, A., Phelps, A.S., Creveling, J.R., Strauss, J.V., Fike, D.A. \& RipPerdan, R.L. 2013. Latest Devonian (Famennian) global events in western Laurentia: variations in the carbon isotopic record linked to diagenetic alteration below regionally extensive unconformities. Palaeogeography, Palaeoclimatology, Palaeoecology 386, 194-209. DOI 10.1016/j.palaeo.2013.05.021

Niebuhr, B. 2005. Geochemistry and time-series analyses of orbitally forced Upper Cretaceous marl-limestone rhythmites (Lehrte West Syncline, northern Germany). Geological Magazine 142, 31-55. DOI 10.1017/S0016756804009999

NowaK, H. 2008. Stratigraphie des höchsten Famenniums bei 
Hemer-Oese (Nordsauerland). 26 pp. Unpublished B.Sc. thesis, WWU Münster.

Oncken, O., Plesch, A., Weber, J., Ricken, W. \& Schrader, S. 2000. Passive margin detachment during arc-continent collision (Central European Variscides), 199-216. In Franke, W., HaAk, V., Oncken, O. \& Tanner, D. (eds) Orogenic Processes: Quantification and Modelling in the Variscan Belt. Geological Society of London, Special Publications 179.

PAPRoth, E. 1986. An introduction to a field trip to the Late Devonian outcrops in the northern Rhenishes Schiefergebirge (Federal Republic of Germany). Annales de la Société géologique de Belgique 109, 275-284.

Paproth, E., Feist, R. \& Flajs, G. 1991. Decision on the Devonian-Carboniferous boundary stratotype. Episodes 14, 331-336.

PAPRoth, E. \& Streel, M. 1970. Corrélations biostratigraphiques prés de la limite Dévonien/Carbonifère entre les facies littoraux ardennais et les faces bathyaux rhénans. Les Congres et Colloques de l'Université de Liège 55, 365-398.

Pollack, G.D., Krogstad, E.J. \& Bekker, A. 2009. U-Th-Pb-REE systematics of organic-rich shales from the ca. 2.15 Ga Sengoma Argillite Formation, Botswana: Evidence for oxidative continental weathering during the Great Oxidation Event. Chemical Geology 260, 172-185. DOI 10.1016/j.chemgeo.2008.10.038

Price, J.D. \& House, M.R. 1984. Ammonoids near the Devonian-Carboniferous boundary. Courier Forschungsinstitut Senckenberg 67, 15-22.

PyE, K. 1987. Aeolian dust and dust deposits. 334 pp. Academic Press, San Diego.

Qie, W., Liu, J., Chen, J., Wang, X., Mit, H., Zhang, X., Huang, X., Yao, L., Algeo, T.J. \& LuO, G. 2015. Local overprints on the global carbonate $\delta^{13} \mathrm{C}$ signal in Devonian-Carboniferous boundary successions of South China. Palaeogeography, Palaeoclimatology, Palaeoecology 418, 290-303.

DOI 10.1016/j.palaeo.2014.11.022

Racka, M., Marynowski, L., Filipiak, P., Sobstel, M., PisaRzowska, A. \& Bond, D.P.G. 2010. Anoxic Annulata Events in the Late Famennian of the Holy Cross Mountains (Southern Poland): Geochemical and palaeontological record. Palaeogeography, Palaeoclimatology, Palaeoecology 297, 549-575. DOI 10.1016/j.palaeo.2010.08.028

RACKI, G. 2005. Towards understanding Late Devonian global events: few answers, many questions, 5-36. In OvER, D.J., Morrow, J.R. \& Wignall, P.B. (eds) Understanding Late Devonian and Permian-Triassic Biotic and Climatic Events: Towards an Integrated Approach. Developments in Palaeontology and Stratigraphy Series 20.

RACHOLD, V. \& BRUMSACK, H.J. 2001. Inorganic geochemistry of Albian sediments from the Lower Saxony basin, NW German: paleoenvironmental constraints and orbital cycles. Palaeogeography, Palaeoclimatology, Palaeoecology 174, 123-144. DOI 10.1016/S0031-0182(01)00290-5

RiDER, M.H. 1999. The geological interpretation of well logs. 288 pp. Whittles Publishing Services.

RimmeR, S.M. 2004. Geochemical paleoredox indicators in Devonian-Mississippian black shales, Central Appalachian Basin (USA). Chemical Geology 206, 373-391.
Rodríguez-Tovar, F.J. \& Reolid, M. 2013. Environmental conditions during the Toarcian Oceanic Anoxic Event (T-OAE) in the westernmost Tethys: influence of the regional context on a global phenomenon. Bulletin of Geosciences 88, 697-712. DOI 10.3140/bull.geosci.1397

Rosales, I., Quaseda, S. \& Robles, S. 2001. Primary and diagenetic isotopic signals in fossils and hemipelagic carbonates: the Lower Jurassic of northern Spain. Sedimentology 48, 1149-1169. DOI 10.1046/j.1365-3091.2001.00412.x

Roy, S. 2006. Sedimentary manganese metallogenesis in response to the evolution of the Earth system. Earth-Science Reviews 77, 273-305. DOI 10.1016/j.earscirev.2006.03.004

SAgeman, B.B. \& Lyons, T.W. 2005. Geochemistry of fine-grained sediments and sedimentary rocks, 115-158. In Mackenzie, F.T. (ed.) Sediments, Diagenesis, and Sedimentary Rocks. Treatise on Geochemistry 7. Elsevier, Amsterdam.

SANDBerg, C.A., Ziegler, W., LeuteritZ, K. \& Brill, S.M. 1978. Phylogeny, speciation, and zonation of Siphonodella (Conodonta, Upper Devonian and Lower Carboniferous). Newsletters on Stratigraphy 7, 102-120.

Schindewolf, O.H. 1937. Zur Stratigraphie und Paläontologie der Wocklumer Schichten (Oberdevon). Abhandlungen der Preußischen Geologischen Landessanstalt, neue Folge 178, $1-132$.

SCHINDLER, E. 1993. Event-stratigraphical markers within the Kellwasser Crisis near the Frasnian/Famennian boundary (Upper Devonian) in Germany. Palaeogeography, Palaeoclimatology, Palaeoecology 104, 115-125. DOI 10.1016/0031-0182(93)90124-2

SChmidT, H. 1924. Zwei Cephalopodenfaunen an der DevonCarbongrenze im Sauerland. Jahrbuch der der Preußischen Geologischen Landessanstalt 44, 98-171.

Schnetger, B., Brumsack, H.J., Schale, H., Hinrichs, J. \& DitTert, L. 2000. Geochemical characteristics of deep-sea sediments from the Arabian Sea: a high-resolution study. Deep Sea Research II 47, 2735-2768.

DOI 10.1016/S0967-0645(00)00047-3

Siegmund, H., Trappe, J. \& Oschmann, W. 2002. Sequence stratigraphic and genetic aspects of the Tournaisian "Liegender Alaunschiefer" and adjacent beds. International Journal of Earth Sciences 91, 934-949.

DOI 10.1007/s00531-001-0252-9

Sliwinski, M.G., Whalen, M.T. \& Day, J. 2010. Trace element variations in the Middle Frasnian punctata Zone (Late Devonian) in the western Canada sedimentary basin - changes in oceanic bioproductivity and paleoredox spurred by a pulse of terrestrial afforestation? Geologica Belgica 4, 459-482.

Smith, M.G. \& Bustin, M.R. 2000. Late Devonian and Early Mississippian Bakken and Exshaw black shale source rocks, Western Canada Sedimentary Basin: a sequence stratigraphic interpretation. AAPG Bulletin 84(7), 940-960.

Steininger, F.F., Aubry, M.P., Berggren, W.A., Biolzi, M., Borsetti, A.M., Cartlidge, J.E., Cati, F., Corfield, R., Gelati, R., Iaccarino, S., Napoleone, C., Ottner, F., Rogl, F., Roetzel, R., Spezzaferri, S., Tateo, F., Villa, G. \& Zevenboom, D. 1997. The Global Stratotype Section and Point (GSSP) for the base of the Neogene. Episodes 20, 23-28. 
Streel, M. 1986. Miospore contribution to the upper Famennian-Strunian event stratigraphy. Annales de la Société Géologique de Belgique 109, 75-92.

Streel, M. 2002. The Uppermost Famennian around the World (definition, biostratigraphical and sedimentological context). SDS Newsletter 18, 55-61.

Streel, M., Caputo, M.V., Loboziak, S., Henrique, J. \& Melo, G. 2000b. Late Frasnian-Famennian climates based on palynomorph analyses and the question of the Late Devonian glaciations. Earth-Science Reviews 52, 121-173. DOI 10.1016/S0012-8252(00)00026-X

Streel, M., Caputo, M.V., Loboziak, S., Melo, J.H.G. \& Thorez, J. 2000a. Palynology and sedimentology of laminites and tillites from the latest Famennian of the Parnaíba Basin, Brazil. Geologica Belgica 3(1/2), 87-96.

Streel, M., Caputo, M.V., Melo, J.H.G. \& Perez-Leyton, M. 2013. What do latest Famennian and Mississippian miospores from South American diamictites tell us? Palaeobiodiversity and Palaeoenvironments 93(3), 299-316.

DOI 10.1007/s12549-012-0109-1

Streel, M. \& Marshall, J. 2007. Devonian-Carboniferous boundary global correlations and their paleogeographic implications for the Assembly of Pangaea, 481-496. In WonG, T.E. (ed.) Proceedings of the $X V^{\text {th }}$ International Congress on Carboniferous and Permian Stratigraphy, Utrecht, the Netherlands, 10-16 August 2003. Royal Netherlands Academy of Arts and Sciences.

Thomson, J., Higgs, N.C., Wilson, T.R.S., Croudace, I.W., De LANGE, G.J. \& VAN SANTwoort, P.J.M. 1995. Redistribution and geochemical behaviour of redox-sensitive elements around S1, the most recent eastern Mediterranean sapropel. Geochimica et Cosmochimica Acta 59, 3487-3501. DOI 10.1016/0016-7037(95)00232-O

Tribovillard, N., Algeo, T.J., Lyons, T. \& Riboulleau, A. 2006. Trace metals as paleoredox and paleoproductivity proxies: An update. Chemical Geology 232, 12-32. DOI 10.1016/j.chemgeo.2006.02.012

Van SteEnwinkel, M. 1984. Sedimentology of the DevonianCarboniferous boundary sediments in the Oberrödinghausen 1 borehole (Germany). Courier Forschungsinstitut Senckenberg 67, 123-137.

VAn Steenwinkel, M. 1993. The D/C boundary: comparison between the Dinant synclinorium and the northern border of the Rhenish Slate Mountains, a sequence-stratigraphic view. Annales de la Société Géologique de Belgique 115, 665-681.

Veevers, J.J. \& Powell, C.McA. 1987. Late Paleozoic glacial ep- isodes in Gondwanaland reflected in transgressive-regressive depositional sequences in Euramerica. Geological Society of America Bulletin 98, 475-487.

DOI 10.1130/0016-7606(1987)98<475:LPGEIG >2.0.CO;2

VEIZER, J. 2009. Carbon isotope variations over geologic time, 128-133. In GoRnitz, V. (ed.) Encyclopedia of Paleoclimatology and Ancient Environments. Springer

VÖHRINGER, E. 1960. Die Goniatiten der unterkarbonischen Gattendorfia-Stufe im Hönnetal (Sauerland). Fortschritte in der Geologie von Rheinland und Westfalen 3, 107-196.

Voges, A. 1960. Die Bedeutung der Conodonten für die Stratigraphie des Unterkarbons I und II (Gattendorfia- und Pericyclus-Stufe) im Sauerland. Fortschritte in der Geologie von Rheinland und Westfalen 3(1), 197-228.

WALLISER, O.H. 1984. Pleading for a natural D/C boundary. Courier Forschungsinstitut Senckenberg 67, 241-246.

Wicander, R., Clayton, G., Marshall, J.E.A., Troth, I. \& RACEY, A. 2011. Was the latest Devonian glaciation a multiple event? New palynological evidence from Bolivia. Palaeogeography, Palaeoclimatology, Palaeoecology 305, 84-92.

DOI 10.1016/j.palaeo.2011.02.016

Wildman, R.A., Berner, R.A., Petsch, S.T., Bolton, E.W., ECKERT, J.O., MoK, U. \& EvANs, J.B. 2004. The weathering of sedimentary organic matter as a control on atmospheric O2: I. Analysis of black shale. American Journal of Science 304, 234-249. DOI 10.2475/ajs.304.3.234

Zhuravlev, A.Y. 1998. The Mid-Tournaisian event in the Northern Urals and conodont dynamics. Proceedings of the Geologists Association 109, 161-168.

DOI 10.1016/S0016-7878(98)80063-1

ZIEGLER, W. 1969. Eine neue Conodontenfauna aus dem höchsten Oberdevon. Fortschritte in der Geologie von Rheinland und Westfalen 17, 343-360.

ZIEGLER, W. 1971. Conodont stratigraphy of the European Devonian. Geological Society of America, Memoir 127, 67-99.

Ziegler, W. \& Leuteritz, K. 1970. Conodonten, 679-732. In Koch, M., Leuteritz, K. \& Ziegler, W. Alter, Fazies und Paläogeographie der Oberdevon/Unterkarbon-Schichtenfolge an der Seiler bei Iserlohn. Fortschritte in der Geologie von Rheinland und Westfalen 17.

Ziegler, W. \& SAndBerg, C.A. 1990. The Late Devonian standard conodont zonation. Courier Forschungsinstitut Senckenberg 121, 1-115.

Ziegler, W. \& SAndBerg, C.A. 1984. Palmatolepis-based revision of upper part of standard Late Devonian conodont zonation. Geological Society of America, Special Paper 196, 179-194. 